Anna SINIARSKA

IEiB UKSW Warszawa

Napoleon WOLAŃSKI

Centro de Investigacion y de Estudios Avanzados, Merida, Meksyk

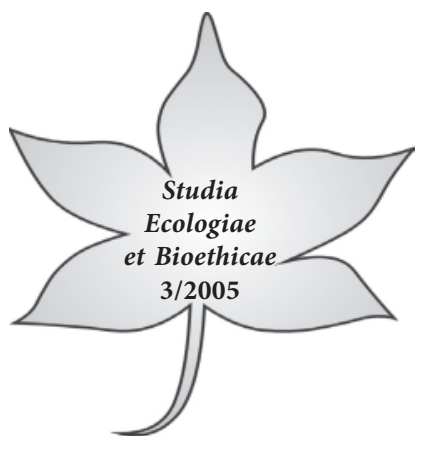

\title{
Zmiany tempa rozwoju w ontogenezie człowieka i metody jego badania
}

\section{Z historii badań nad wzrastaniem dzieci i młodzieży}

Od dawna obserwowano nierównomierność tempa rozwoju. Prawdopodobnie pierwszym, który wykonał badania przekrojowe i opracował tabele norm był niemiecki lekarz Jampert w roku 1754. Natomiast pierwsze badania ciągłe wykonał francuski hrabia Montbeillard, który pod wpływem wielkiego przyrodnika Buffona (1707-1788) mierzył swego syna od wieku 6 miesięcy (w roku 1759) do 17,5 lat (w roku 1777). Dokonywał tego dwa razy w roku, w kwietniu i w październiku. Już w wykonanych przez niego pomiarach można dostrzec kilka skokowych przyrostów wysokości ciała, co najmniej czterech przedpokwitaniowych, jak również dwóch pokwitaniowych. W późniejszych opisach tempa wzrastania wskazywano, że istnieje kilka okresów przyspieszonego i spowolnionego wzrastania. Tak więc w latach 1905-1914 niemiecki ginekolog Stratz (1858-1924) wyróżniając okres wczesnego i późnego dzieciństwa wspominał o trzech okresach zwolnionego wzrastania przedzielonych dwoma okresami przyspieszonego wzrastania. W okresie tzw. pierwszego dzieciństwa wskazywał na okres zwolnionego wzrastania w wieku 2-4 lat i okres przyspieszonego wzrastania w 5-7 roku życia, w okresie drugiego dzieciństwa miałby mieć miejsce okres zwolnionego wzrastania w wieku 8-10 lat, a okres przyspieszonego wzrastania w wieku 11-15 lat, trzeci okres zwolnionego wzrastania miałby występować około 16-20 rok życia. Wiek kalendarzowy występowania owych okresów (zjawisko akceleracji w ramach tendencji przemian) jest w kolejnych pokoleniach coraz wcześniejszy, ale istota zjawiska pozostaje nadal aktualna. Zmieniony też został podział i nazwy etapów, faz i okresów ontogenezy (tab. 1). 
Anna Siniarska i Napoleon Wolański

Tabela 1. Wspótcześnie wyróżniane etapy, fazy i okresy w rozwoju osobniczym człowieka (Wolański 2005).

\begin{tabular}{|c|c|c|c|}
\hline Etap & Faza & Okres & Czas trwania \\
\hline \multirow{3}{*}{$\begin{array}{l}\text { Rozwój progre- } \\
\text { sywny prenatalny } \\
\text { (śródmaciczny) }\end{array}$} & Jaja płodowego & & $\begin{array}{l}\text { Pierwszy tydzień } \\
\text { od zapłodnienia }\end{array}$ \\
\hline & Zarodka & & 8-56 dzień od zapłodnienia \\
\hline & Płodowa & & Od 57 dnia do urodzenia \\
\hline \multirow{5}{*}{$\begin{array}{l}\text { Rozwój progre- } \\
\text { sywny postnatalny } \\
\text { (po urodzeniu) }\end{array}$} & Bierności & Wczesnego niemowlęctwa & $\begin{array}{l}\text { Od urodzenia } \\
\text { do 5-7 miesięcy }\end{array}$ \\
\hline & \multirow{4}{*}{ Ekspansji } & $\begin{array}{l}\text { Późnego niemowlęctwa } \\
\text { i poniemowlęcy }\end{array}$ & $\begin{array}{l}\text { Od 5-7 miesięcy } \\
\text { do 2,5-3 lat }\end{array}$ \\
\hline & & Dzieciństwa & Od 2,5-3 do 6-7 lat \\
\hline & & $\begin{array}{l}\text { Młodociany (przedpokwi- } \\
\text { taniowy) }\end{array}$ & Od 6-7 do 10-12 lat \\
\hline & & $\begin{array}{l}\text { Młodzieńczy (pokwitanio- } \\
\text { wy i dorastania) }\end{array}$ & Od 10-12 do 18-20 lat \\
\hline $\begin{array}{l}\text { Równowagi } \\
\text { (względnej) }\end{array}$ & & & Od $18-20$ do $55-60$ lat \\
\hline \multirow{3}{*}{$\begin{array}{l}\text { Zmian inwolucyj- } \\
\text { nych (starości) }\end{array}$} & Wieku starszego & & Od 60 do 75 lat \\
\hline & Wieku starczego & & Od 75 do 90 lat \\
\hline & $\begin{array}{l}\text { Wieku głębokiej } \\
\text { starości }\end{array}$ & & Powyżej 90 lat do śmierci \\
\hline
\end{tabular}

Skokowy przyrost wysokości ciała ze zjawiskiem dojrzewania płciowego powiązał jako pierwszy w roku 1930 amerykański antropolog Boas (1858-1942), nazywając go skokiem pokwitaniowym.

Występowanie dwóch okresów przyspieszonego wzrastania wynika z jednych z pierwszych badań longitudinalnych, mianowicie rozpoczętych w Krakowie już od 1909 roku, a kontynuowanych po I wojnie światowej w latach 1919-1932. W pracach Jasickiego (1938a), opartych na powyższych badaniach longitudinalnych męskiej młodzieży szkolnej, widnieje ów skokowy przyrost wysokości ciała $\mathrm{z} 7$ na 8 rok życia (str. 39), który daje się także zaobserwować dla długości oraz szerokości głowy (str. 83 i 90), twarzy (str. 140) i nosa (str. 183). Jednak na fakt dodatkowych skoków przedpokwitaniowych i pokwitaniowych długo nie zwracano uwagi, podkreślając jedynie występowanie wzmiankowanego powyżej skoku pokwitaniowego (np. Shuttleworth 1939).

Z badań Jasickiego (1948a, b) wynika, że: (1) wielkość „maksymalnego przyrostu" (tak autor nazywa skok pokwitaniowy) wysokości ciała (nazwijmy go więc MPWC) jest względnie stała w danej populacji niezależnie od tego w jakim wieku on się rozpoczyna, (2) nie ma on też związku z typem morfologicznym osobnika i jego aktualną wysokością ciała, (3) zakończenie wzrastania ciała na wysokość następuje 5-6 lat po MPWC, (4) jednak im później pojawia się MPWC, tym szybciej następuje zakończenie wzrastania („stabilizacja wysokości”), (5) a wiek w jakim występuje MPWC nie ma związku z charakterem krzywej wzrastania, to jest 
ani z kinetyką ani z dynamiką zmian wysokości ciała. Ani przesunięcie w czasie wystąpienia MPWC, ani jego charakter w wyodrębnionych przez Jasickiego kilku typach morfologicznych nie wpływa na wymienione powyżej prawidłowości, natomiast przynależność do konkretnego zespołu morfologicznego czy typu antropologicznego zdaje się decydować o wieku, w jakim występuje przyspieszenie bądź zwolnienie rozwoju. Siła impulsów wzrostowych wydaje się być uwarunkowana genetycznie („,rytm rozwojowy wysokości ciała zdaje się być właściwością gatunkową" - Jasicki 1948b, str. 117). Jego zdaniem jedynie w indywidualnych przypadkach osobnicy dojrzewający wcześniej są wyżsi od tych, którzy dojrzewają później.

Powyższe dane uzyskane w badaniach ciągłych dzieci krakowskich nie w pełni znajdują jednak potwierdzenie dla innych populacji, stąd sprawę należy uznać nadal za otwartą. Większość danych wskazuje bowiem, że im wcześniej występuje skok pokwitaniowy, tym większy jest przyrost osiągany w tym samym czasie (Shuttleworth 1937, 1939, Bielicki 1976). Istnieje więc ujemna korelacja między tymi dwoma objawami (Deming 1957). Wiadomo także, że gdy skok pokwitaniowy występuje wcześniej, krótszy jest wiek, jaki dzieli go od wystąpienia menarche (Simons i Greulich 1943, Wolański 1964). Nie ma także uchwytnej korelacji między szybkością rozwoju mierzoną wiekiem występowania menarche a „dorosłą" wysokością ciała (Bielicki 1976), co nie wyklucza takiej zależności dla ogólnego tempa rozwoju. Dzieci wcześniej dojrzewające więcej bowiem przyrastają w okresie skoku pokwitaniowego, a dzieci późno dojrzewające mniej, lecz dłużej wzrastają, w wyniku czego następuje złagodzenie różnic międzyosobniczych właściwych dla osób dorosłych.

Według badań ciągłych dzieci poznańskich (Kaczmarek 2002): (1) intensywność skoku pokwitaniowego jest związana $\mathrm{z}$ wiekiem, w jakim on występuje, u dziewcząt wcześnie dojrzewających jest on bardziej intensywny (wynosi ponad $9 \mathrm{~cm} / \mathrm{rok}$ ), aniżeli u dojrzewających później (mniej niż $6 \mathrm{~cm} / \mathrm{rok}$ ); (2) szczytowy przyrost wysokości ciała jest większy u chłopców $(9,3 \mathrm{~cm} / \mathrm{rok})$, aniżeli u dziewcząt $(7,4 \mathrm{~cm} /$ rok); (3) zazwyczaj wcześniejszy skok pokwitaniowy trwa dłużej oraz większy jest szczytowy przyrost wysokości ciała; (4) wiek, w jakim rozpoczyna się skok pokwitaniowy oraz długość jego trwania nie wpływają na ostateczną wysokość ciała i ta ostatnia nie jest skorelowana $\mathrm{z}$ badanymi przez tę autorkę właściwościami skoku pokwitaniowego, ani z wiekiem wystąpienia menarche.

Występowanie kilku skoków przedpokwitaniowych i pokwitaniowych wykazał dla wysokości ciała Wolański (1961b) w badaniach dzieci warszawskich. Z kolejnej pracy wynikało, że skoki we wzrastaniu mają miejsce dla wielu innych cech somatycznych (Wolański 1962a) oraz, że skok pokwitaniowy jest znacznie wyraźniejszy u chłopców aniżeli u dziewcząt, a u tych ostatnich podzielony jest na kilka przyrostów (Wolański 1964, Wolański i Pyżuk 1970). W Warszawie nie przeprowadzono jednak badań longitudinalnych, a wyniki oparte były na pomiarach przekrojowych (jednorazowych pomiarach dzieci w różnym wieku). 
Nazwa skoku (spurt) pochodzi stąd, że w poprzednich i następnych latach przyrost roczny wynosi po 2-3 centymetry, podczas gdy w czasie skoku pokwitaniowego nawet ponad $10 \mathrm{~cm}$ rocznie. Łącznie przyrost wysokości ciała w okresie pokwitania wynosi około $20-25 \mathrm{~cm}$. Rzecz jednak w tym, że w pewnych warunkach jest on rozłożony na 2-3 lata, w innych nawet na lat 5. Okres występowania najszybszego wzrastania w ciągu jednego roku zwany jest szczytowym przyrostem wysokości ciała (peak height velocity - $P H V$ ).

Większość cech wykazuje mniejsze podobieństwo między rodzeństwem przy porównaniu w klasach wieku kalendarzowego, a większe przy porównaniach w klasach wieku rozwojowego (Tanner 1963). Także skok pokwitaniowy jest ściślej związany z poziomem rozwoju, aniżeli z wiekiem kalendarzowym (Palmer i wsp. 1937). Przemawia to za silniejszą kontrolą rytmu występowania poszczególnych objawów rozwoju, niż wielkości bezwzględnej cech. Wcześniej dojrzewający chłopcy są w tym okresie więksi od swych później dojrzewających rówieśników, jednak ci ostatni później kończą wzrastanie (Garn 1966). Skok pokwitaniowy wcześniej występujący jest bardziej intensywny (Shuttleworth 1937, 1939, Deming 1957, Kaczmarek 2002).

Istnieje natomiast kontrowersja, co do „ostatecznych” („dorosłych”) wymiarów ciała. Istnieją dane, że niezależnie od wieku występowania skoku pokwitaniowego, dane osoby jako dorośli osiągają podobną średnią wysokość ciała (Howe i Schiller 1952). Większość jednak danych przemawia za tym, że im później następuje maksymalny wzrost ciała na długość (skok pokwitaniowy), tym większą wysokość ciała osiąga dana grupa morfologiczna bezpośrednio po skoku (Jasicki 1948a,b). W wyniku dłuższego rośnięcia zarówno dziewczęta, jak i chłopcy późno dojrzewający są jako dorośli wyżsi (Stone i Barker 1937), a szczególnie dłuższe są u nich kończyny dolne (Shuttleworth 1939) i szersze barki (Bayley 1943) niż u tych, którzy dojrzewają wcześnie. Wcześnie dojrzewający są natomiast w każdej klasie wieku starsi fizjologicznie, a jako dorośli ciężsi niż dojrzewający później (Pryor 1936, Reynolds i Wines 1948, Boothby i wsp. 1952 i inni). Być może wiąże się to z tym, że dziewczęta endomorficzne i chłopcy mezomorficzni szybciej się rozwijają niż ektomorficzni (Barker i Stone 1936, Wallau 1939, Kralj-Čerček 1956, Acheson i Dupertuis 1957, Tanner 1963) lub, że wcześnie dojrzewający, a więc szybciej rozwijający się wykazują większą tendencję do gromadzenia zapasów tkanki tłuszczowej. Występuje tu jednak konkurencja między energią potrzebną dla przyrostu kości, a gromadzeniem tkanek miękkich (w tym tłuszczu) - dotyczy to problemu naprzemienności okresów tzw. bujania i pełnienia. W czasie skoku pokwitaniowego ma miejsce zmniejszenie akumulacji tkanki tłuszczowej (Pyżuk 1964, Jaczewski i Pyżuk 1965). Już jednak Frisch (1974, 1988) wykazywała (choć istnieją na ten temat kontrowersje), że dziewczęta muszą osiągnąć pewną masę krytyczna (chodziło głównie o akumulację tkanki tłuszczowej) aby nastąpiło dojrzewanie płciowe. $\mathrm{Z}$ naszych badań wykonanych 
w Meksyku (Siniarska i wsp. 2004, Wolański i wsp. 2004) wynika, że dziewczęta $\mathrm{z}$ lepszych warunków bytowych są znacznie wyższe, aniżeli z warstw ubogich i występują między nimi także różnice w nagromadzeniu masy tłuszczu, jednak pomimo to, różnice $\mathrm{w}$ wieku wystąpienia menarche nie są między nimi istotne statystycznie.

Ostatnio Hulanicka i wsp. (2005) wykazali, że istnieje związek pomiędzy gromadzeniem się tkanki tłuszczowej a wiekiem dojrzewania płciowego i otłuszczeniem w dorosłości. Rola tkanki tłuszczowej jest tu niezależna od wskaźnika wagowo-wzrostowego Kaupa (BMI). Osoby wcześnie dojrzewające mają silniejszą tendencję do odkładania tkanki tłuszczowej w okresie dorosłości, niż dojrzewający później ${ }^{1}$. Istnieją współcześnie poglądy, że otyłości sprzyja występowanie określonej predyspozycji genetycznej, domniema się nawet występowania odpowiedniego genu odpowiedzialnego za to zjawisko. Nasuwa się jednak także przypuszczenie, że osoby wcześnie dojrzewające były po prostu lepiej odżywiane, w którymś z okresów od dzieciństwa po pokwitanie. Wiadomo już z wielu badań, że wcześniej dojrzewają osoby spożywające więcej białka zwierzęcego oraz pochodzące z zamożniejszych rodzin. Można więc również wysunąć przypuszczenie, że owe osoby obficiej żywione w dzieciństwie, gromadziły więcej tkanki tłuszczowej i wcześniej dojrzewały. Stąd tendencja do gromadzenia się tkanki tłuszczowej mogła również powstać na skutek przekarmiania we wcześniejszych okresach ontogenezy i ukształtowania się metabolizmu sprzyjającego odkładaniu tkanki tłuszczowej w dalszym życiu.

Od dawna było już wiadomo, że gdy młodzież podzielimy na grupy na podstawie wieku, w którym występuje skok pokwitaniowy, wykażą one odrębne tory rozwoju (Boas 1930, 1932-35, Shuttleworth 1939), co potwierdzono dzieląc dziewczęta według różnego wieku wystąpienia menarche (Bocheńska i Panek 1966). Już od dawna badania różnic w rozwoju dzieci zamieszkujących ziemie polskie prowadziło z punktu widzenia odrębności antropologicznych i etnicznych wielu badaczy (np. Talko-Hryncewicz 1908, Schreiber 1910, Lipiec 1912). Powyższe dane nie interpretowano jednak w kategoriach uwarunkowań genetycznych.

Dla stworzenia genetycznej koncepcji rozwoju pierwsze podstawy dali jednak polscy badacze Gryglaszewska-Puzynina (1937), Jasicki (1938ab, 1948ab)

1 Przez kilka lat począwszy od roku 1997 autorzy niniejszej pracy składali projekty badań do KBN o dotację na powtórne po 30 latach badania ludności Suwalszczyzny i Kurpi, które prowadzili w sposób półciągły w latach 1959-67. Już przed kilku laty mogliśmy wyświetlić omawiane zjawisko, a także wpływ żywienia i trybu życia na budowę ciała tych samych osób badanych w wieku dziecięcym lub w młodości, w wieku 40-70 lat oraz przebieg procesów starzenia. Dotacji odmówiono na skutek ataku recenzentów. 
i Sikora (1949) w swych badaniach nad zróżnicowaniem przebiegu rozwoju rozmaitych cech u przedstawicieli poszczególnych typów antropologicznych. Już Spitzer-Willerowa (1919) wskazywała na związki między barwą włosów, kształtem głowy i twarzy a wysokością ciała. Ponad pół wieku później Grabowska (1973) stwierdziła, że dzieci różniące się pigmentacją oczu i włosów, wykazują różnice w szeregu cechach: co do wysokości ciała różnice te są niewielkie, większe pod względem szerokości twarzy, jeszcze większe odnośnie wysokości twarzy, a największe z pośród badanych cech co do kształtu (wskaźnika) twarzy. $\mathrm{Z}$ wyjątkiem wysokości ciała, różnice te były znacznie większe między dziećmi o różnej pigmentacji aniżeli z miast i wsi. $Z$ cytowanych prac wynikało więc, że pewne typy morfologiczne wykazują swoiste dla siebie szlaki rozwoju.

Ponieważ owe szlaki rozwoju wyodrębniono na podstawie cech innych niż te, które szlaki tworzyły (jak to miało miejsce w analizach Boasa i kontynuatorów), można było się domyślać genetycznego podłoża tego zjawiska. Nie można jednak odrzucić także znaczenia czynników paragenetycznych matczynych, bowiem osobnicy podzieleni na kohorty według masy urodzeniowej wykazują w dalszym przebiega rozwoju odrębne szlaki wzrastania wysokości i masy ciała.

Tego rodzaju liczne już obserwacje mogły dowodzić, że „wzór” rozwoju jest uwarunkowany genetycznie. Wiele danych wskazuje przy tym na to, że tempo rozwoju jest w pierwszym rzędzie regulowane czynnikami żywieniowymi, podczas gdy wiek zarastania nasad kości długich głównie czynnikami genetycznymi. Końcowy wynik rozwoju kości miałby być więc wypadkową działania determinantów genetycznych i modyfikatorów środowiskowych (Garn 1962, 1966). Nie wiadomo, w jakim stopniu ten model jest powszechny. W każdym razie można sądzić, że tempo rozwoju jest sprzężone $\mathrm{z}$ końcowym wynikiem wzrastania, aczkolwiek mechanizm związku między wydatkiem energetycznym, a wiekiem zakończenia wzrastania, pozostaje niejasny.

Według poglądów Jasickiego (1948ab) wielkość skoku pokwitaniowego jest niezależna od wieku, typu morfologicznego osobnika i jego wysokości aktualnej, co miałoby być dowodem, że rytm rozwoju jest ogólną właściwością gatunkową. Natomiast przynależność do konkretnego zespołu morfologicznego czy typu antropologicznego zdaje się decydować jedynie o wieku, w jakim występuje przyspieszenie bądź zwolnienie rozwoju, nie określa natomiast siły tych impulsów. Nie przesądzając o realności występowania typów antropologicznych ${ }^{2}$ można

2 Pojęcie typu antropologicznego (raczej odmiany) miałoby sens, jak zakładał to Czekanowski kilkadziesiąt lat temu, gdyby odmiana charakteryzowała się zespołem sprzężonych genów, które dziedziczą się jako całość. Uważane wcześniej za absurdalne, po wykryciu major genes, regulatorów itp., takie twierdzenie stało się bardziej prawdopodobne. Ono też jedynie może być podstawą wyodrębniania podziałów wewnątrz gatunków, które są hermetyczne pod względem rozrodu, w zasadzie nie ma płodnych krzyżówek między gatunkowych (por. referaty na sympo- 
jednak przyjąć, że zróżnicowanie tempa rozwoju osobniczego jest podstawowym procesem w formowaniu odrębności morfologicznej (Sikora 1949, Jasicki 1966, Bocheńska i Panek 1966). Dotyczy to zarówno samego procesu wzrastania, jak również finalnej wielkości ciała osób dorosłych.

Skok pokwitaniowy składa się z pewnej sekwencji przyspieszonych przyrostów różnych części ciała (tab. 2). Z reguły jako pierwsze odnotowywane są skokowe przyrosty długości kończyn dolnych, jedynie w jednych badaniach jako pierwsze podano obwody ramienia i podudzia (Gethner i wsp. 1999). Natomiast w badaniach wrocławskich odnotowano wczesne skoki długości stopy i ręki (dłoni z nadgarstkiem) (Welon i Bielicki 1979). Najpóźniej natomiast u obu płci występuje skokowy przyrost masy ciała. Istnieją jednak pewne rozbieżności, co do kolejności przyspieszenia wzrastania pozostałych części ciała (tab. 2). Wydaje się, że ogólną prawidłowością jest jednak najwcześniejszy skok pokwitaniowy części dystalnych (stopy i dłoni), natomiast najpóźniejszy - proksymalnych, bliższych głowy (szerokość barków i głowy z szyją).

zjum - Bergman i inni 2005). Pojęcie grupy etnicznej odnoszone do ludzi o innym wyglądzie, jest jeszcze bardziej niepoprawne politycznie, aniżeli przez wielu uważane za kontrowersyjne pojęcie rasy. Po pierwsze, szczególnie współcześnie wymordowują się raczej grupy odrębne etnicznie, niekiedy religijnie, aniżeli odmiany (rasy). Po drugie odmiany są widoczne gołym okiem, są to różnice wyglądu, biologiczne - natomiast grupy etnicznej różnią się kulturą, a więc mogą być wartościowane. Odmiany ludzkie są od siebie różne, po prostu inne, odmiennym kulturom w takim samym środowisku przypisuje się różne wartości. Człowiek o innym wyglądzie nie musi różnić się kulturą. Odmiany są obiektywne, kultury - subiektywne. Język, kulturę, wyznanie można samemu zmienić - odmiany (rasy) - nie. Według genetyków ponad 75\% różnic genetycznych to różnice wewnątrzpopulacyjne, a tylko $25 \%$ to różnice międzypopulacyjne. $\mathrm{Na}$ tej podstawie zakwestionowano występowanie rasy czy odmiany jako jednostki biologicznej. Zdaniem B. Pawłowskiego, jeśli jednak „różnice te dotyczą tylko określonej grupy genów (a tak jest np. w przypadku ras), czyli nie sa losowe w obrębie ludzkiego genomu, to jednak można, czy nawet trzeba, brać to pod uwage. Te genetyczne różnice, obecnie np. zaczynają być ważne dla epidemiologów i medyków - sq ewidentnie odmienne miedzy rasami, jeśli chodzi, np. o podatność na różne choroby, a różnice genetyczne powoduja, że powinno się dla nich stosować nieco inne leki etc.” Dodajmy, że różnice między przedstawicielami odmiany białej i czarnej zamieszkującymi Stany Zjednoczone dotyczą nawet czasu trwania ciąży. Od dawna głoszono, a stosunkowo od niedawna się to stosuje, że lek musi być dozowany odpowiednio do wieku czy masy ciała. A zapewne także do biochemicznych właściwości organizmu, a te mogą być związane z genetycznymi odrębnościami, być może $\mathrm{z}$ płcią, a nawet $\mathrm{z}$ okresowym stanem organizmu, obciążeniem wysiłkiem, sposobem żywienia, porą dnia, u kobiety dodatkowo z cyklem miesięcznym. Już teraz w produkowanej w Stanach wysokiej klasy aparaturze badawczej (np. do badań spirometrycznych czy impedancji) wprowadza się dane o przynależności rasowej, jako poprawki do komputerowych wyliczeń o pochodnych badanych właściwości. 
Anna Siniarska i Napoleon Wolański

Tabela 2. Wiek występowania skoku pokwitaniowego niektórych wymiarów i masy ciała u dzieci wrocławskich i poznańskich. Na pierwszym miejscu podano kolejność skoku w danej kohorcie, na drugim wiek (w latach) występowania szczytu skokowego przyrostu wielkości danej cechy (dane Welona i Bielickiego 1979 oraz Kaczmarek 2001)

\begin{tabular}{|l|c|c|c|c|}
\hline \multirow{2}{*}{\multicolumn{2}{|c|}{ Cecha }} & \multicolumn{2}{c|}{ Młodzież wrocławska } & \multicolumn{2}{c|}{ Młodzież poznańska } \\
\cline { 2 - 5 } & Dziewczęta & Chłopcy & Dziewczęta & Chłopcy \\
\hline Długość stopy & $1-10,6$ & $1-13,0$ & & \\
\hline Długość kończyn dolnych & $2 \mathrm{a}-11,2$ & $2-13,6$ & $1-11,38$ & $1-12,25$ \\
\hline Długość ręki (dłoni z nadgarstkiem) & $3 \mathrm{a}-11,5$ & $3 \mathrm{a}-14,0$ & & \\
\hline Długość kończyn górnych & & & $2-11,54$ & $4-13,56$ \\
\hline Szerokość bioder & $2 \mathrm{~b}-11,2$ & $3 \mathrm{~b}-14,0$ & $5-12,25$ & $3-13,55$ \\
\hline Długość tułowia & $5 \mathrm{a}-12,3$ & $6-14,4$ & $4 \mathrm{a}-12,00$ & $2-13,28$ \\
\hline Wysokość głowy z szyją & & & $4 \mathrm{~b}-12,00$ & $5-13,65$ \\
\hline Wysokość całego ciała & $4-11,7$ & $5 \mathrm{a}-14,2$ & $3-11,79$ & $6-13,88$ \\
\hline Szerokość barków & $3 \mathrm{~b}-11,5$ & $4-14,1$ & $6-12,31$ & $7-13,90$ \\
\hline Masa ciała & $5 \mathrm{~b}-12,3$ & $5 \mathrm{~b}-14,2$ & $7-12,50$ & $8-13,94$ \\
\hline $\begin{array}{l}\text { Czas między najwcześniejszym } \\
\text { i najpóźniejszym przyrostem } \\
\text { w latach }\end{array}$ & 1,7 & 1,4 & 1,12 & 1,69 \\
\hline
\end{tabular}

Trwanie skoku pokwitaniowego wszystkich wymienionych w tabeli 2 cech licząc od najwcześniejszego do najpóźniejszego szczytu wynosi od 1,12 do 1,7 roku, co jednak nieoczekiwane, dłuższy jest on u wrocławskich dziewcząt niż chłopców oraz u poznańskich chłopców niż dziewcząt. Powstaje pytanie czy występuje tu w takim razie jakaś prawidłowość dotycząca płci.

Jest rzeczą zastanawiającą, że nie analizowano, dlaczego skok pokwitaniowy całkowitej wysokości ciała jest odmienny od jego składowych, a łatwo wyliczyć, że u młodzieży wrocławskiej oraz dziewcząt poznańskich znajduje się on logicznie po środku wieku skoku długości kończyn dolnych i tułowia, jedynie u chłopców poznańskich dopiero po przyrostach kończyn dolnych, tułowia oraz głowy z szyją (Welon i Bielicki 1979, Kaczmarek 2001, str. 117).

Skok pokwitaniowy dotyczy niemal wszystkich cech, w tym np. grubości kości czaszki, która w tym czasie przyrasta o $15 \%$. Nie dotyczy natomiast, o ile dotychczas wiadomo, objętości mózgu, kostek ucha wewnętrznego, rozwoju zębów oraz rozwoju niektórych gruczołów. Skok pokwitaniowy, manifestujący się szczególnie intensywnym przyrostem długości kończyn dolnych, wpływa na przemieszczenie się środka ciężkości ku górze. To z kolei powoduje zmiany nachylenia miednicy oraz krzywizn kręgosłupa (Wolański 1958, 1961a).

Zastanawiające jest natomiast istnienie pewnego genetycznego sterowania tempem rozwoju $\mathrm{w}$ ramach ontogenezy, skoro stwierdzono korelację między urodzeniową masą ciała, a wysokością ciała w momencie rozpoczynania skoku pokwitaniowego i w jego szczycie oraz wysokością „dorosłą” (Kaczmarek 2001). Być może, masa urodzeniowa stanowi pewien wskaźnik potencji biologicznej 
osobnika. Takie znaczenie przypisuje się testowi dr Wirginii Apgar. Wiek rozpoczynania skoku pokwitaniowego nie wpływa na „dorosłą” wysokość ciała, wpływa natomiast na nią wielkość skoku pokwitaniowego (Kaczmarek 2001).

Z powyższego zestawienia wynika, że istnieją rozbieżności, co do oceny przebiegu skokowych przyrostów wielkości i masy ciała oraz ich współzależności z wiekiem wystąpienia i zakończenia tego zjawiska, intensywnością oraz wymiarami ciała w okresie występowania skoku. Odmienność interpretacji skokowych przyrostów wynikać może z przekrojowego lub ciągłego charakteru posiadanych danych, odstępów czasu w dokonywanych pomiarach (dobowe, miesięczne, roczne) oraz sposobu analizy przyrostów (stosowanej metody ich wyrównywania). $\mathrm{O}$ ile dwie pierwsze przyczyny są $\mathrm{w}$ jakimś stopniu nieodzownym następstwem, o tyle trzecia $\mathrm{z}$ nich stanowi zafałszowanie wyników badań empirycznych.

\section{Dotychczasowe ustalenia}

\subsection{Nierównomierność i niejednostajność tempa wzrastania}

Badania prowadzone codziennie wskazują, że proces wzrastania nie jest jednostajny, tak w okresie doby, dni, tygodni, miesięcy jak i lat mają miejsca zmiany tempa rozwoju. Istnieją jednodniowe skokowe przyrosty (saltations, mini-spurts, steep changes), między nimi znajduje trwające kilka dni przerwy we wzrastaniu (stasis), które być może są zmianami nieuchwytnymi przy pomocy stosowanych metod (w granicach błędu pomiarowego - no significantly detected changes zwane stasis) (Lamp i wsp. 1992, 1993; Caino i wsp. 2004). Thalange i wsp. (1996) znajdują u zdrowych "normalnych" dzieci zmiany dwufazowe to jest mini-skoki przedzielone okresami spoczynku. Przyrosty i pauzy są raczej nieregularne, chaotyczne (Wales i Gibson 1994). Z rzadka jedynie obserwowany jest proces ciągłego wzrastania (continuous growth changes).

Z badań comiesięcznych wykonanych w latach 2002-2003 na Jukatanie w Meksyku (Siniarska i wsp. 2004, Wolański i wsp. 2004) wynika, że: (1) brak jest (a) istotnych prawidłowości zmian sezonowych dla całej badanej grupy, (b) podobieństwa comiesięcznych zmian chłopców w porównaniu z dziewczętami, (c) indywidualne zróżnicowanie tempa rozwoju występuje zarówno wśród Indian Maja, jak Kreoli i Metysów oraz nie jest ono odmienne ze względu na przynależność etniczną; (2) każde dziecko i każda jego cecha ma swoiste tempo rozwoju, przypuszczalnie jest ono modyfikowane przez warunki życia w danym okresie; oraz że (3) obserwowane zmiany (a) nie wydają się być związane z rytmiką przyrody i nie mają one cyklicznego charakteru, (b) natomiast pewne regularności zmian tempa rozwoju związane sa z rytmem roku szkolnego oraz okresem ferii „zimowych” i wakacji letnich. Wynikają one ze zmiany trybu życia wraz z rozpoczynaniem wakacji i powrotem do reżimu szkolnego. Mogą jednak w lecie doty- 
czyć także nasłonecznienia. Na Jukatanie w kwietniu-maju liczba godzin pełnej operacji przy bezchmurnym niebie wynosi 7,5 godziny, podczas gdy w porze deszczowej jedynie 5 godzin (Wolański i wsp. 1998). Tak silna operacja słoneczna powoduje zwiększoną syntezę w skórze cholekalcyferolu (witaminy $\mathrm{D}_{3}$ ), następnie modyfikowanego $\mathrm{w}$ wątrobie i nerkach, co przypuszczalnie wiąże się z przyspieszeniem dojrzewania płciowego (wystąpieniem menarche - Wolański i wsp. 1998), oraz stymulacją wzrastania.

$Z$ dotychczasowych badań wynika, że dzienne, miesięczne i sezonowe zmiany tempa wyrastania nie mają charakteru rytmów endogennych, ani związanych z rytmiką przyrody, są to raczej okazjonalne zmiany przystosowawcze. Prawidłowością jest jedynie, że gdy dziecko w jednym okresie (zależnie od częstotliwości pomiarów stwierdzano to odnośnie jednego dnia lub miesiąca, rzadziej - kilku) intensywniej rośnie, to w kolejnym (częściej kolejnych) rośnie wolniej lub pauzuje.

Owa nierównomierność procesów wzrastania ma jednak pewną ogólną endogennie uwarunkowaną prawidłowość w odniesieniu do całej ontogenezy (zjawisko stadialności), która z kolei jest prawidłowością w procesie filogenezy. Między poszczególnymi jej ogniwami (pokoleniami) dokonują się bowiem zmiany ukierunkowujące proces ewolucji, to jest dokonują mutacje w gametach oraz selekcja pojawiającej się zmienności. Kiedyś była ona ukierunkowana, obecnie w związku z ochronną działalnością kulturową (medycyna, opieka społeczna) ma charakter stabilizujący (na obu krawędziach rozkładu zmienności).

\subsection{Przyrosty skokowe}

\section{Okresy bujania i petnienia}

Spornym problemem jest występowanie okresów bujania (zwiększonych przyrostów wysokości ciała, przy zahamowaniu lub małych - masy ciała) i pełnienia (zwiększonych przyrostów masy ciała, przy zahamowaniu lub małych - wysokości ciała). Na ich istnienie zwrócił uwagę cytowany poprzednio Stratz (1905 cyt. wg 1926), a poparli ten punkt widzenia Abel (1940) i Harris (1947). Na ich istnieniu oparty był podział na okresy rozwoju dzieci i młodzieży. Twierdzeniu temu przeciwstawili się Mydlarski (1934), Jasicki (1938b) i Bocheńska (1958, str. 16, ryc. 5), stwierdzając, że w procesie rozwoju stosunek masy do wysokości pozostaje mniej więcej stały, zmiany są równoległe, a okresy przyspieszonego lub powolnego rozwoju dotyczą w zasadzie wszystkich wymiarów. Natomiast wrażenie pełnienia lub bujania sprawiają wahania w zasobach podskórnej tkanki tłuszczowej.

Nowsze badania jednak zjawisko przedstawiają w nieco innym świetle. W trakcie rozwoju osobniczego następują zarówno zmiany zasobów podskórnej tkanki tłuszczowej (Garn 1976, Wolański 1998a,b) jak i wskaźnika wagowo- 
-wzrostowego Kaupa (powszechnie obecnie znanego pod nazwa body mass index - BMI). Oba te procesy wskazują podobny kierunek zmian (Wolański 1998a, ryc. 7, 2005, ryc. 183-184). W tym świetle należy stwierdzić, że w trakcie ontogenezy istnieją okresy silniejszego gromadzenia się tkanki tłuszczowej oraz przybierania na wadze aniżeli wzrastania, oraz okresy szybszego wzrastania aniżeli przybierania na wadze (np. tzw. ubytek przedszkolny u obu płci, ubytek pokwitaniowy jedynie u chłopców) oraz na odwrót (przyrost przedpokwitaniowy).

W badaniach comiesięcznych wykonanych w klimacie tropikalnym stwierdziliśmy, że nie występuje konkurencja o energię lub składniki budulcowe, a raczej okresy szybszych przyrostów wysokości (bujania) niż masy lub masy niż wysokości ciała (pełnienia). Badania wykonane były w uboższych warstwach społeczeństwa, a więc potencjalnie taka konkurencja miała szansę wystąpić. Zgodność kierunku zmian masy i wysokości ciała jest losowa, w około połowie przypadków jest zgodna, w drugiej połowie rozbieżna (Wolański i wsp. 2004).

\section{Skoki przed okresem pokwitania}

Na występowanie skoku w przyrostach wysokości ciała około 6-7 roku życia zwracało uwagę wielu autorów (Backman 1934, Meredith 1935, Meredith i Boynton 1937, Gray $1941 \mathrm{i}$ inni), a Tanner (1947) nawał go mid-growth spurt. Nieznający wówczas tych prac Wolański (1962a, str. 81) zwrócił uwagę ma dwa skoki, wg jego terminologii skok szkolny występujący u obu płci w wieku 6-7 lat oraz skok nazwany przez niego przedpokwitaniowym w wieku 8-9 lat u dziewcząt i 9-10 u chłopców. Także w opublikowanych siatkach (gridach) "graficznej metody oceny tempa i harmonii rozrostu” zaznaczono „krzywe przyrostów rocznych wysokości ciała", które szczególnie dla dziewcząt przewidywały kilka skoków ${ }^{3}$ przed okresem pokwitania między 4 a 9 rokiem życia (Wolański 1961b). Odrębne także były owe przyrosty, szczególnie w okresie pokwitania dla chłopców szczupłych, harmonijnie się rozwijających i tęgich (ryc. 1).

3 W rozwoju polskiej auksologii wyróżnić można kilka etapów. Pierwszym z nich było rozpoczęcie w Krakowie badań longitudinalnych przez Talko-Hryncewicza w 1909 roku oraz badań przekrojowych w latach 1912-13 (Spitzer-Willerowa 1919) i na ich podstawie wyróżnienie odrębnych torów rozwoju dla typów antropologicznych u chłopców przez Jasickiego (1938-48). Badania te wyprzedzały amerykańskie (Shuttleworth 1937, 1939), jednak nie zostały spopularyzowane za granicą, zarówno z powodu bariery językowej jak i na skutek wybuchu wojny. Drugim etapem było stwierdzenie nierównomierności tempa rozwoju przez wyróżnienie kilku skokowych przyrostów wysokości ciała przed pokwitaniem (Wolański 1961a,b, 1962a,b), który to problem nie został jednak wówczas podjęty przez innych badaczy. Poprzednio podnoszono występowanie jedynie jednego skoku przed pokwitaniem. Trzeci etap rozpoczęły badania nad rozwojem dzieci z różnych warstw społecznych Warszawy (Brzeziński 1964) i Szczecina (Wolański 1970, 1972), który to sposób dekadę później użyto jako miary nierówności społecznych w cyklu wspaniałych publikacji w ośrodku wrocławskim (Bielicki i Welon 1982, oraz współpracownicy), głównie jednak dotyczących poborowych. 

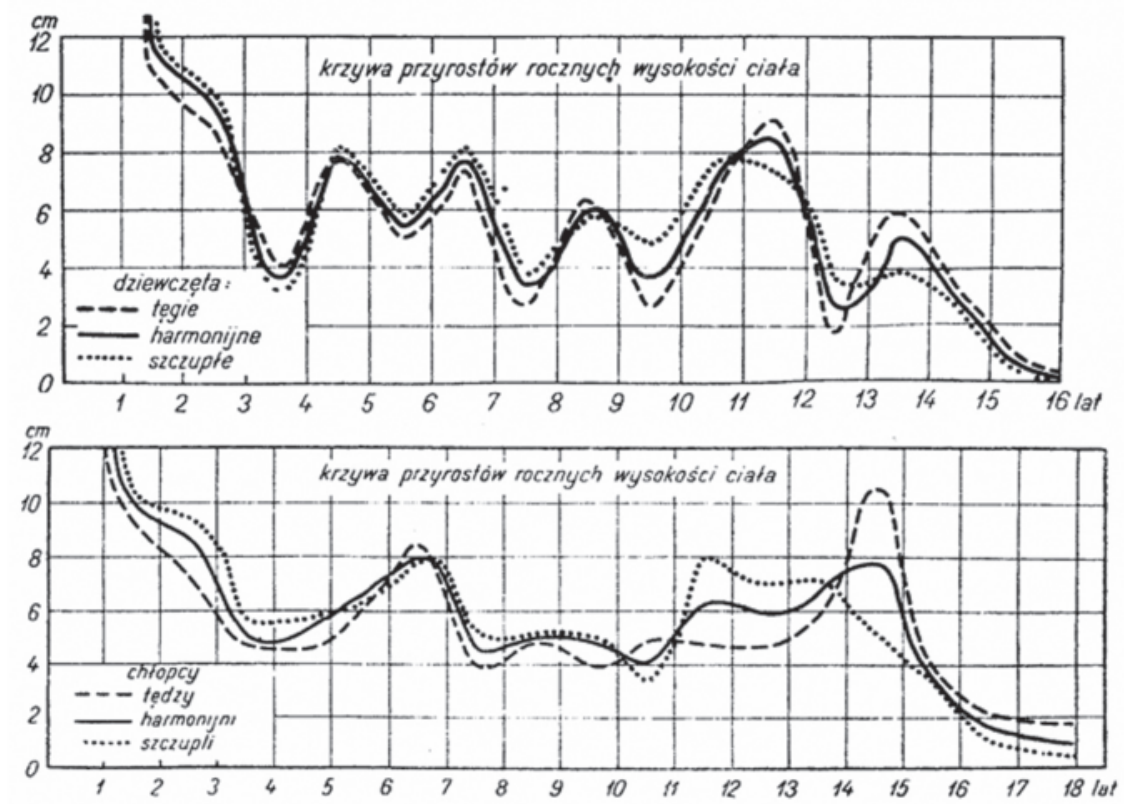

Rycina 1. Krzywe przyrostów rocznych dla dzieci szczupłych, charmonijnie się rozwijających i tęgich, wyróznione w badaniach przekrojowych (Wolański, 1961b).

Pogląd o występowaniu jednego skoku na przełomie dzieciństwa i okresu młodocianego około 6-7 roku życia został dwie dekady potem potwierdzony w kilku publikacjach (Bock i Thissen 1980, Stützle i wsp. 1980, Gasser i wsp. 1985). Występowanie kilku takich skoków potwierdził Butler i wsp. (1990). Stosując inne metody odwzorowania krzywych Ramsay i wsp. (1995) porównując wyniki trzech serii badań longitudinalnych wskazywali, że u 22\% chłopców z Ohio i Zurychu oraz 12\% z Berkeley, a także u 16\% dziewcząt ze wszystkich wymienionych ośrodków występowały dwa skoki przedpokwitaniowe.

Współcześnie przedpokwitaniowe skokowe przyrosty wysokości ciała (PPS) są wiązane nie tylko $\mathrm{z}$ wydzielniczą aktywnością kory nadnerczy (adrenarche) oraz wysuwane jest przypuszczenie, że liczba PPS zależy od czynników środowiskowych i nie jest uwarunkowana genetycznie. Wskazuje się przy tym, że u chłopców zazwyczaj występuje 2-3 PPS, u dziewcząt jedynie 1-2, a liczba PPS u danego osobnika wpływa na czas ich pojawiania się (Bock 2004).

Każde przyspieszenie rozwoju jest związane z kosztem energetycznym. Przy mniejszej liczbie PPS przypuszczalnie następuje akumulacja sił witalnych i dlatego wcześniej występuje skok pokwitaniowy (AS), który związany jest z przyspieszeniem pokwitaniowej aktywności wydzielniczej gonad (gonadarche). 


\section{Skok pokwitaniowy}

Dziecko w ciągu pierwszego roku życia przyrasta około $25 \mathrm{~cm}$, to jest tyle ile maksymalnie wynosi skok pokwitaniowy, ale ten ostatni trwa od 2 do 5 lat. U niemowlęcia wynosi to więc średnio ok. $0,7 \mathrm{~mm}$ na dzień, pół $\mathrm{cm}$ na tydzień, 1 $\mathrm{cm}$ na 2 tygodnie. Ale niemowlę 1-2 dni rośnie, potem kilka dni pauzuje (ryc. 2, Lampl i wsp. 1992). W okresie pokwitania owe przerwy we wzrastaniu są dłuższe, a wielkość przyrostów jest rozłożona na kilka lat (ryc. 3, Lampl i Johnson 1993).

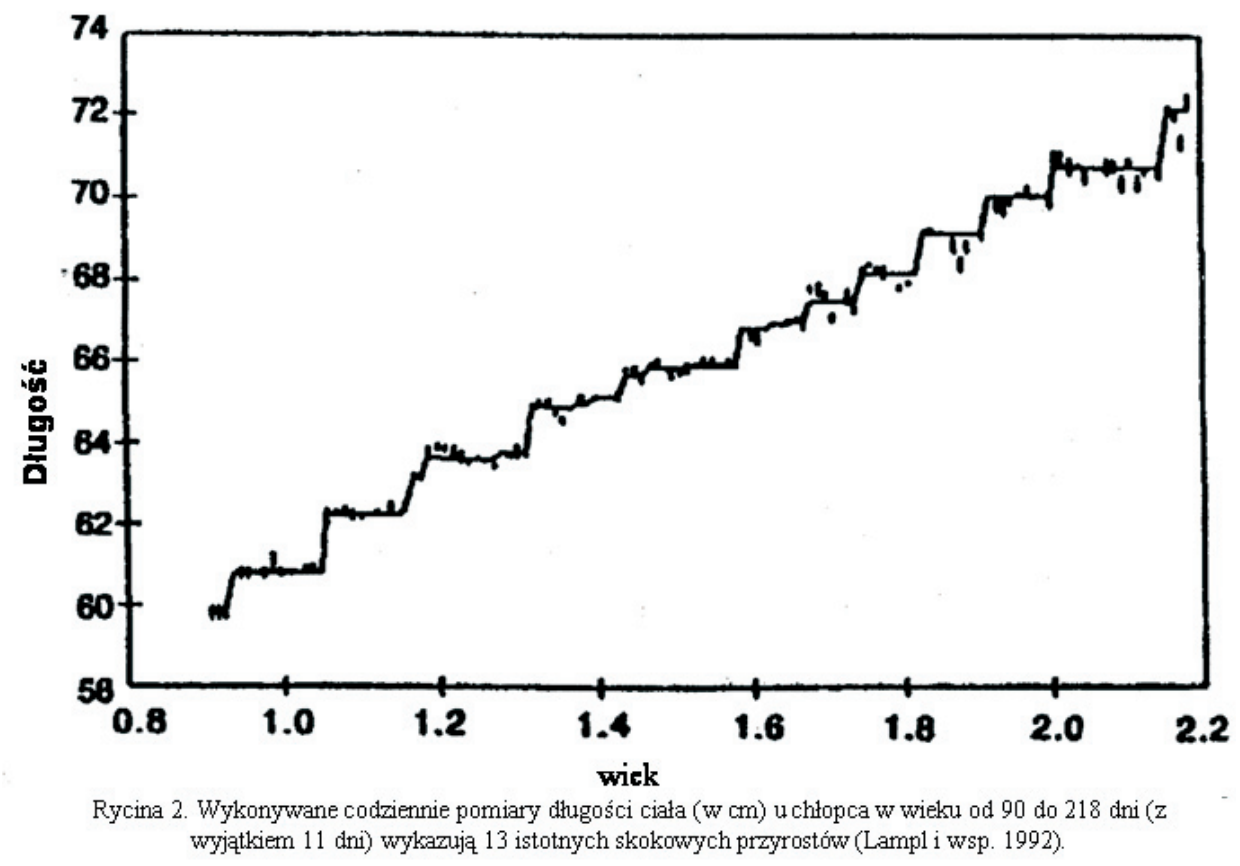

Jasicki (1938a,b, 1948a,b ${ }^{4}$ ) opierając się na badaniach ciągłych (longitudinalnych), jako pierwszy podzielił dzieci na grupy według typów antropologicznych, wykazując, że w ramach każdej z tak utworzonych grup wykazują one odmienne szlaki rozwoju (ryc. 4).

4 Na Uniwersytecie Jagiellońskim przed wojną, a nawet w czasie, gdy jedno z nas (NW) było tam, na tzw. studiach aspiranckich (później zwanych doktoranckimi) w latach 1954-57, panował zwyczaj, że napisaną pracę chowało się do szuflady, co najmniej na rok. Po tym czasie ponownie ją czytano i jeśli nie zmieniono zdania, posyłano do publikacji. Przed wysłaniem do druku prace były przedstawiane na posiedzeniu Polskiej Akademii Umiejętności (PAU) przez profesora kierującego Zakładem, lub innego członka PAU, z ośrodka, w którym pracował dany autor. Opóźniało to publikowanie prac o kilka lat i niekiedy powodowało utratę priorytetu. Sytuację tę pogłębiła przerwa spowodowana wojną, w wyniku tego wyniki prac Jasickiego, których publikację rozpoczął w roku 1934 i realizował do 1938 roku, zakończone zostały dopiero w roku 1948. Długi był wówczas także cykl wydawniczy na skutek braku kadr i „mocy drukarskich”, zajętych głównie drukiem broszur propagandowych. 

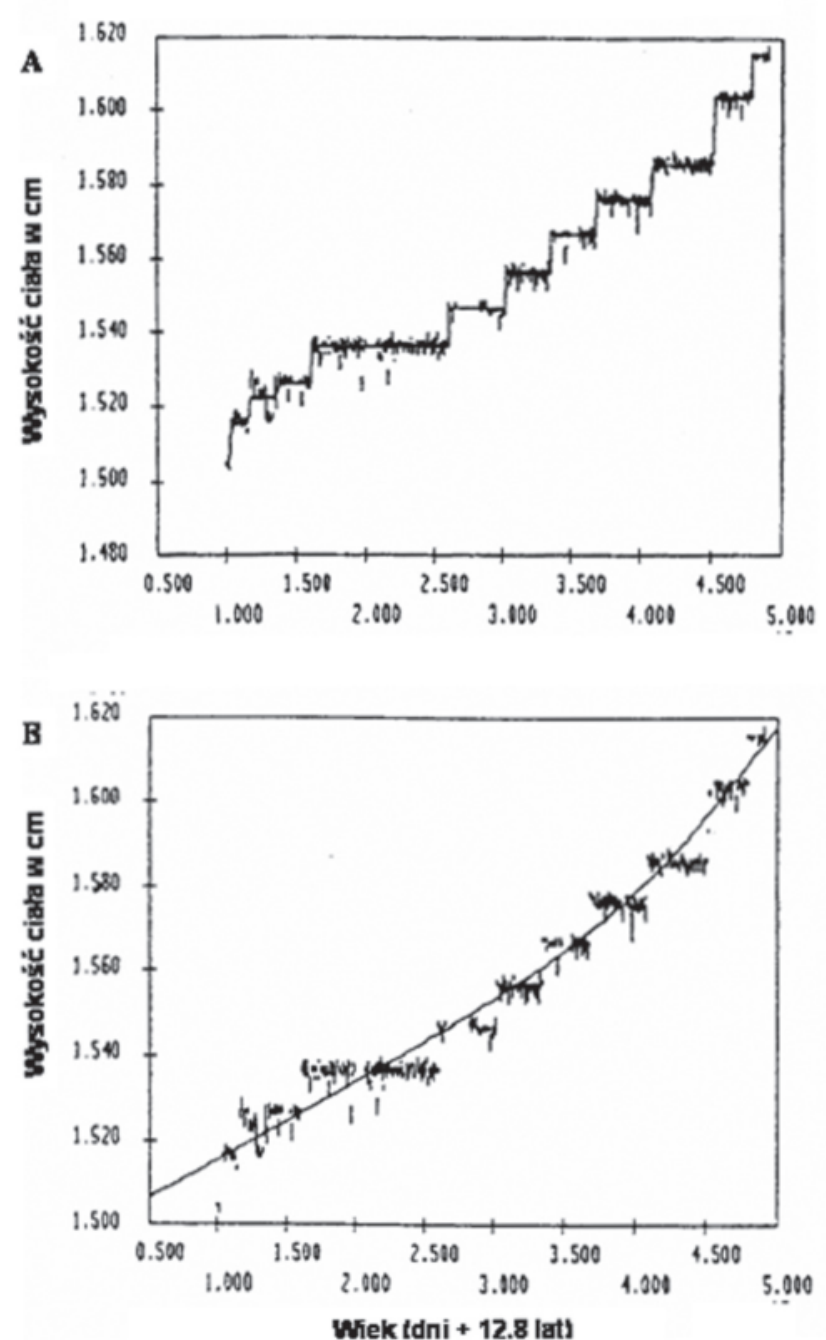

Rycina 3. (A) Wykonywane codziennie pomiary wysokości ciała u pokwitającego chłopca od 12,83 do 13,95 lat wykazują 12 istotnych skokowych przyrostów. Ponizej (B) ta sama rycina po wyrównaniu metodą Karlberga, co zaciera skokowy charakter procesów wzrastania (Lampl i Johnson, 1993).

W badaniach chłopców krakowskich stwierdzono różnice wieku występowania skoku pokwitaniowego wysokości ciała od 12/13 do 17/18 roku życia (ryc. 5 - Jasicki 1948b) i skoki te niewiele różniły się pod względem wielkości, a czas ich trwania dla każdej z grup wynosił około 2-3 lata. Natomiast, gdy grupy odrębne pod względem wieku występowania skoku połączono razem, skok był mniej intensywny i rozciągnięty w czasie do 5 lat. Podobną analizę wykonał Shuttleworth (1939) dla dzieci amerykańskich obojga płci dla wysokości ciała, wysokości siedzeniowej oraz długości 


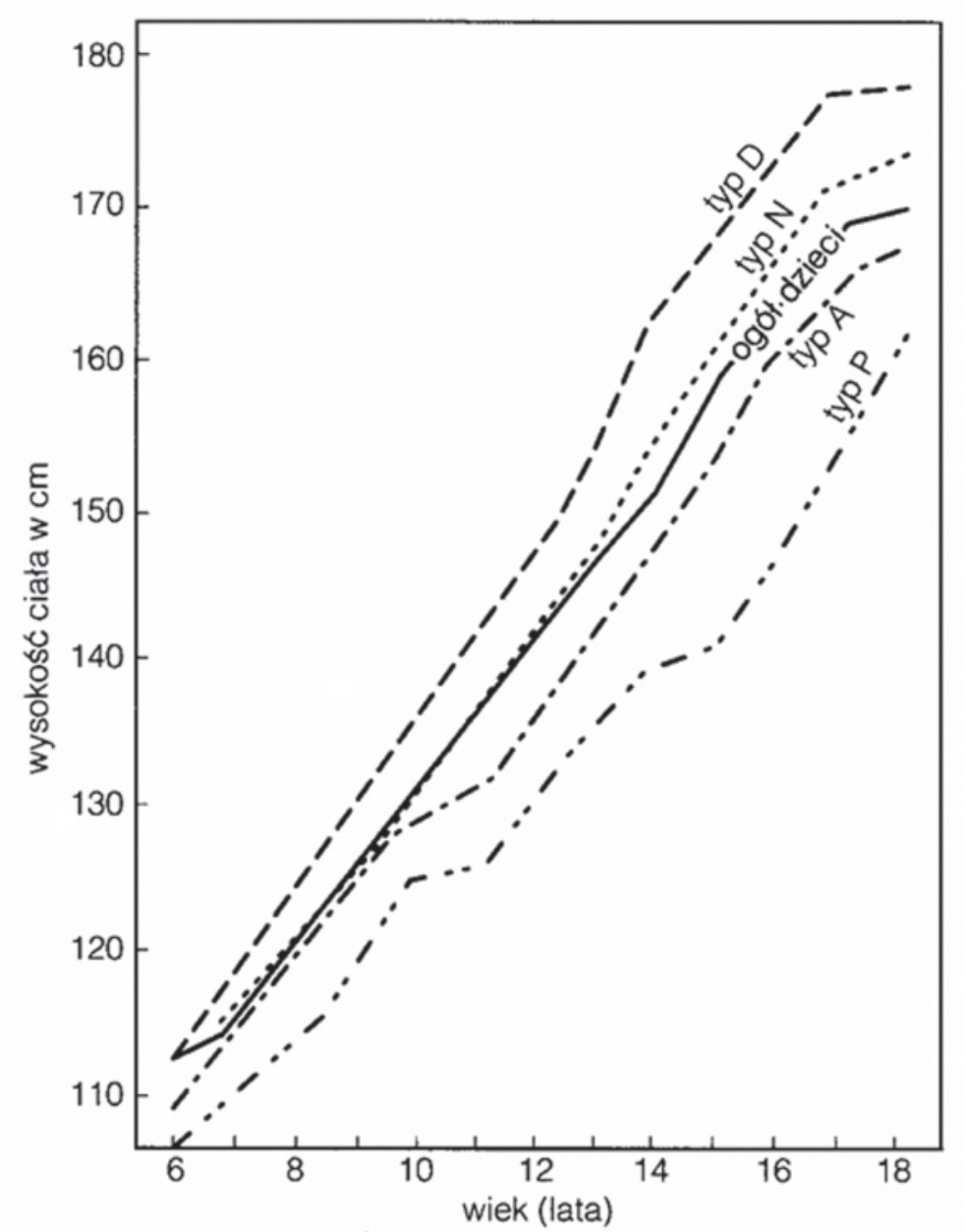

Rycina 4. Tory rozwoju wysokości ciała u dzieci krakowskich przy podziale na typy morfologiczne (Jasicki, 1948).

kończyn dolnych, jednak w jego badaniach skoki występujące w wieku od 12,5 do 17 lat były tym większe im we wcześniejszym wieku miały miejsce.

Po przyjęciu jako punkt wspólny wystąpienie szczytu skoku pokwitaniowego wysokości ciała (PHV) (ryc. 6) stwierdzono, że trwa on w danej populacji, niezależnie od wieku jego występowania, ok. 2-3 lata (Jasicki 1948b). Jednak w tych ostatnich badaniach u dojrzewających później mniej stromy jest wzrost przyspieszenia tempa wzrastania, a szybszy jego spadek, podczas gdy u dojrzewających w przeciętnym lub wczesnym wieku dla tej kohorty, gwałtowniejszy jest przyrost na początku a powolniejsze jego obniżanie się (ryc. 7). 
Okres przyspieszonego rozwoju wysokości ciała w okresie pokwitania, wynoszący średnio $20 \%$ całego postnatalnego przyrostu trwa kilka lat. Początek skoku pokwitaniowego masy tkanek aktywnych (LBM) u dziewcząt rozpoczyna się około 11 roku, okres intensywnych przyrostów trwa w latach 12-14, kończy około 16-17 roku życia, u chłopców okres intensywnych przyrostów zaczyna się około 14 roku i trwa do wieku 20 lat - u tych ostatnich jest 5-krotnie intensywniejszy niż u dziewcząt. Wynikiem dłużej trwającego i intensywniejszego wzrastania jest większa wysokość ciała chłopców
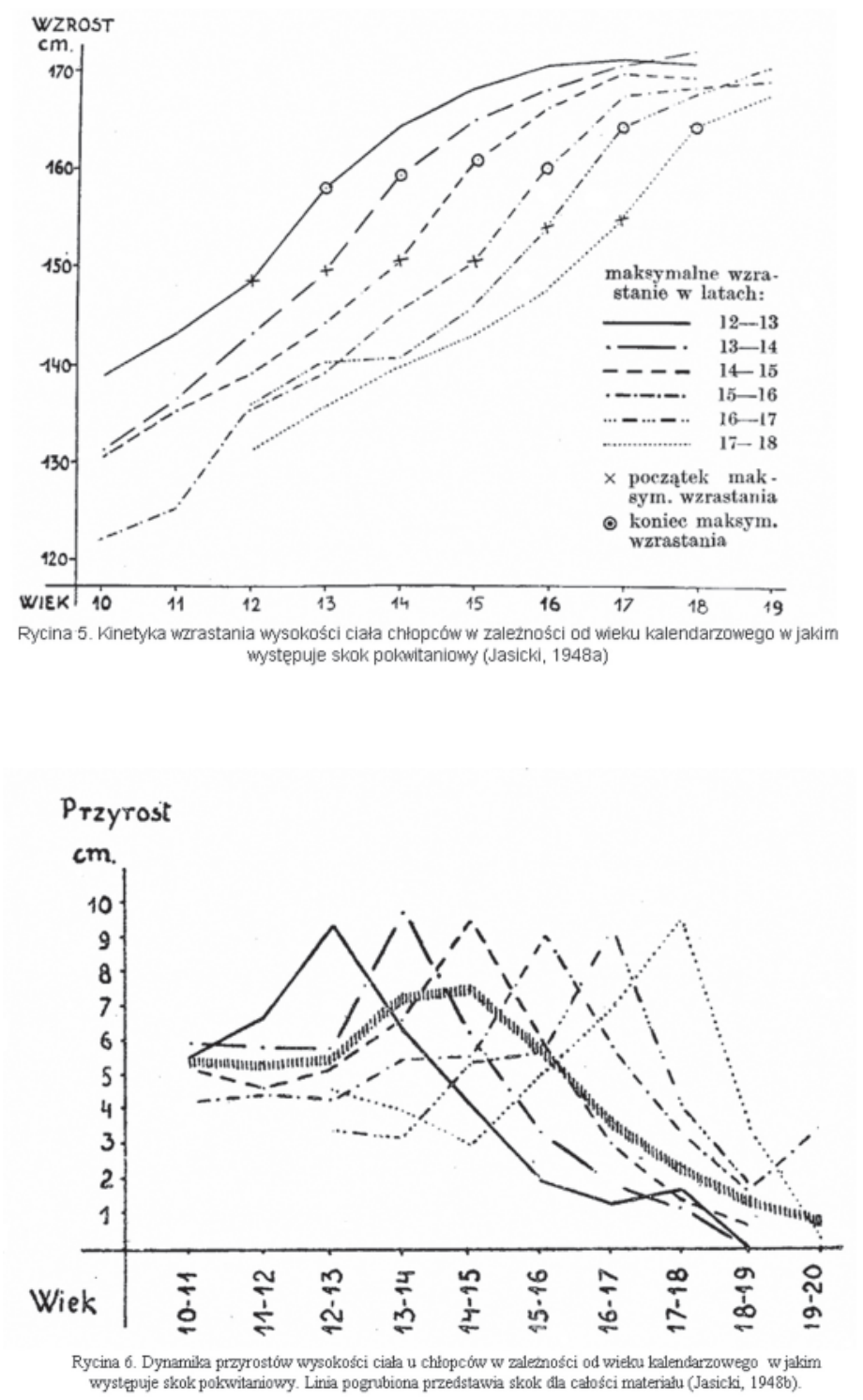


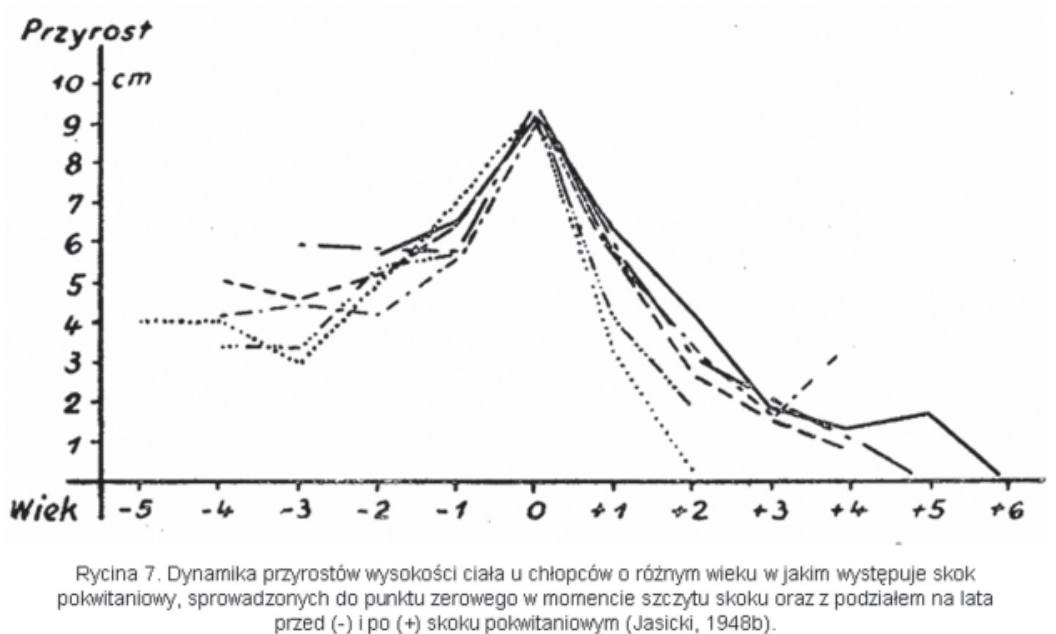

aniżeli dziewcząt. U dziewcząt przyrosty tkanki tłuszczowej, w okresie skoku pokwitaniowego wysokości ciała, są mniejsze, aby ponownie zwiększyć się w wieku 14 - 16 lat, czyli już po wystąpieniu menarche. Siła mięśniowa ze wzrastającą intensywnością narasta w okresie 14-16 lat, po osiągnięciu pełnych znamion dojrzałości (cech drugorzędnych), a więc bynajmniej nie w wieku narastania masy ciała, dotyczy więc przypuszczalnie różnicowania i dojrzewania jednostek motorycznych (układ nerw-mięsień). Największe zróżnicowanie w kohorcie wiekowej masy ciała (mierzone SD) występuje około rok później, aniżeli obserwowane dla wysokości ciała.

Młodzież z krajów rozwijających się oraz z gorszych warunków bytowych wykazuje wydłużony skok pokwitaniowy, zaś z krajów i warstw społecznych o dobrych warunkach bytowych skok ten jest skoncentrowany w krótszym czasie.

\section{Pożytki i zaniechania wynikające ze stosowania schematów matematycznych w badaniach rozwoju biologicznego}

Inny aspekt tych samych zjawisk interesuje matematyków, a inny przedstawicieli nauk biomedycznych. $Z$ różnego pojmowania procesów rozwoju wynika odmienność podziałów na okresy i terminologii między naukami biologicznymi (por. tab. 1), medycyną i naukami społecznymi, w tym pedagogiką. Jak inne to są punkty widzenia wskazują rozbieżności między podziałami dokonywanymi w psychologii i biologii, oraz wynika to także ze stopnia rozwoju tych nauk. Matematyka operuje ilościowym i formalnym odwzorowaniem zjawisk. Biologia jest nauką daleko zaawansowaną w eksperymentalnej sprawdzalności swoich twierdzeń, psychologia ciągle jeszcze jest nauką wnioskującą z ogólnych przejawów, operującą niesprawdzonymi eksperymentalnie aksjomatami, opartymi o teoretyczne założenia. Istnieje jednak i obiektywna przyczyna odmienności podziału, która wynika z charakteru 
kształtowania się osobowości z jednej strony, a istnienia pewnych utajonych faz $\mathrm{w}$ czasie rozwoju biologicznego, $\mathrm{z}$ drugiej. Wymienione procesy somatyczne i psychiczne wyłamują się z ram „poprawności” matematycznej i na tym polega znaczenie ich badań dla teorii i praktyki biologii i medycyny.

Urodzony w Polsce francuski matematyk Benoit Mandelbrot wskazuje, że stosowana już od czasów greckich geometria opisuje świat w uproszczonej formie regularnych linii prostych, bądź wielokątów czy okręgów. Natomiast w naturze takie regularne kształty zdarzają się raczej jako wyjątek. Szczyty gór nie są stożkowate, chmury nie są kuliste, nie jest gładka kora drzew. Próbę opisania błyskawicy przez połączenie miejsca jej poczęcia z miejscem rozładowania linią prostą uznano by za niedorzeczność, błyskawice biegną zygzakami. Geometria rzeczywistego wszechświata, w tym naszego globu pełna jest najdziwaczniej przebiegających linii, które nazwał fraktalami. Owe poplątane linie i nieregularne kształty powierzchni i brył dają się jednak ująć powtarzanymi w nieskończoność algorytmami, co bliższe jest układom chaotycznym aniżeli uporządkowanym. Powyższe odnieść można do matematycznych prób odwzorowania krzywych rozwoju człowieka, kursów giełdowych, wzrostu produkcji przemysłowej, mikroanatomii naszych organizmów, a nawet budowy kryształów.

Już przed wojną pod wpływem matematyków Mydlarski (1934, por. np. dla chłopców str. 46, ryc. $9 \mathrm{i}$ dla dziewcząt str. 119, ryc. 1) na materiałach badań przekrojowych i naśladując go Jasicki (1938b, str. 35, ryc. 8) na materiałach ciągłych próbowali wyrównywać krzywą rozwoju, Mydlarski dla wielu cech, w tym sprawności fizycznej młodzieży ogólnopolskiej, Jasicki dla wysokości ciała chłopców krakowskich.

Matematyk próbuje sztucznie owe skomplikowane linie uporządkować. W konsekwencji wszystkie matematyczne metody wyrównywania krzywych (Pineau 1965, Healy 1978, Largo i wsp. 1978, Marubini 1978, Preece i Baines 1978, Preece i Henrich 1981, Gasser i wsp. 1984, 1990, 1991a,b, Karlberg 1989, 1990, 1998, Karlberg i wsp. 1987, 1994, Jolicoeur i wsp. 1992, Bock i wsp, 1994) doprowadziły do zafałszowania zjawisk rozwoju i opóźniły ujawnienie istniejących zjawisk przyrodniczych. Na przykład Hermanussen w 1988 roku używając specjalnych metod do analizy dobowych przyrostów stwierdził istnienie pewnych cykli w rozwoju, które okazały się efektem zastosowanej metody i w kolejnej pracy z 1995 roku uznał swą wcześniejszą interpretację za błędną. Przypuszczalnie pogląd swój zrewidował w związku z badaniami Butlera i wsp. (1990), którzy wskazali na istnienie cyklu przyspieszeń wzrastania w okresie przedpokwitaniowym. Także Hauspie (1998) i Kaczmarek (2003) w nowszych publikacjach pokazują istnienie kilku takich przyspieszeń.

Wyrównywanie krzywych odzwierciedlających zmiany rozwojowe czy np. wahania masy ciała jednostki ma sens jedynie dla ewentualnego wyeliminowania błędów pomiarowych z powodu ustawienia obiektu badań, przyrządu pomiarowego lub predyspozycji badacza (np. sprawności manualnej). Podobne zresztą 
znaczenie ma wyrównywanie krzywych dla grupy. Wyrównywanie krzywych wynikających z badań przekrojowych ma większe uzasadnienie, bowiem każda kohorta w danej klasie wieku stanowi nieco inną próbkę populacji, nawet, gdy użyto takiej samej metody losowania. O ile próbka jest dostatecznie duża, a pomiary wykonywał ten sam wykwalifikowany personel w porównywalnych warunkach, postępowanie takie jest zbędne, a nawet nie ma sensu gdyż prowadzi do zamazania zjawiska przyrodniczego.

Przy wyrównywaniu krzywych empirycznych (zmierzonych) wynikają pewne tzw. reszty (odchylenia). Im mniej owych reszt, tym uważa się, że dany wzór matematyczny lepiej oddaje przebieg rozwoju biologicznego. Owe reszty można zresztą wyrównać przy pomocy regresji harmonicznej, to jest uzupełniających wzorów (tzw. harmonik). Powstaje jednak pytanie, po co to czynić, skoro antropologa i lekarza interesują właśnie owe odchylenia od genetycznie zdeterminowanego indywidualnego szlaku $i$ typowego $\mathrm{w}$ danej populacji toru rozwoju. Owe odchylenia obrazują bowiem rzeczywisty (empiryczny) przebieg rozwoju, a celem badań biomedycznych jest dociekanie przyczyn odchyleń $w$ indywidualnych losach osobnika, doszukiwanie się prawidłowości reakcji organizmu o danym genotypie na warunki życia.

Po wprowadzeniu matematycznego wyrównywania krzywych rozwoju, zastosowanie pracochłonnej i uciążliwej metody badań powtarzanych (ciągłych, longitudinalnych) traci swą przewagę nad metodą badań przekrojowych (wykonywanych jedynie raz na kolejnych kohortach wieku). Matematyczne wyrównanie może mieć sens właśnie w badaniach przekrojowych. Optymalną zaś metodą byłyby badania półcią̧łe, przy powtórzeniu badań co rok, dwukrotnie w roku, a jeszcze lepiej co kwartał w ciągu jednego tylko roku i badanie kohort o rocznym interwale. Poszukiwanie odwzorowania krzywych indywidualnych z badań longitudinalnych jest sztuką dla sztuki, nie przydatną dla poznania procesów biologicznych.

Jeszcze w roku 2001, Kaczmarek w dwóch miejscach swej monografii (str. 28 i 125) opartej o longitudinalne badania poznańskie, podaje inny (i to różny o około rok) wiek występowania trzech skoków w okresie dzieciństwa, na skutek oparcia się na odmiennych metodach wyrównywania krzywych rozwojowych. Może to najdobitniej wskazuje na zagrożenia wynikające ze stosowania owych metod. Wydaje się, że wyrównywanie krzywych ręką wprawnego badacza jest mniej dowolne i odbiegające od rzeczywistości, aniżeli stosowanie sformalizowanych metod matematycznych.

Gdy wykreśliliśmy na podstawie wyliczeń Bocka (2004) tory rozwoju osobników, którzy wykazywali różną liczbę skoków przed okresem pokwitania, szlaki te znalazły się na jednej linii, a miejsca skoków, poza jednym przypadkiem, nie odbiegały od owej linii prostej (ryc. 8), także szlaki rozwoju chłopców i dziewcząt leżały na jednej linii. W pewnym stopniu tłumaczy to fakt, że skoki te wyznaczono od ich początku do szczytu, a więc jedynie połowa skoku jest tu uwzględniona, a druga włączona do następnego okresu rozwoju. Od linii tej odstaje nato- 
miast fragment odpowiadający skokowi pokwitaniowemu dla osobników, którzy nie wykazywali skoków przed okresem pokwitania. Dyskwalifikujące taki sposób upraszczania toru rozwoju jest to, że przyrost pokwitaniowy dla chłopców leży na przedłużeniu tej samej linii prostej, która właściwa jest dla dziewcząt. Tego rodzaju sformalizowany przez operacje matematyczne wykres rozwoju jest niezgodny z empirycznym przebiegiem wzrastania (ryc. 9).

$\mathbf{A}$

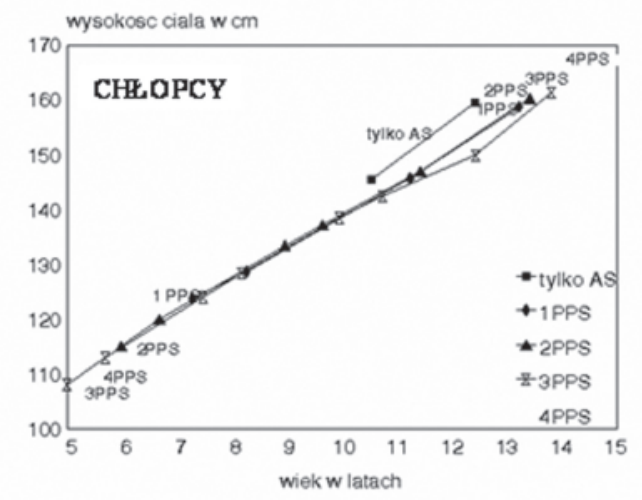

B

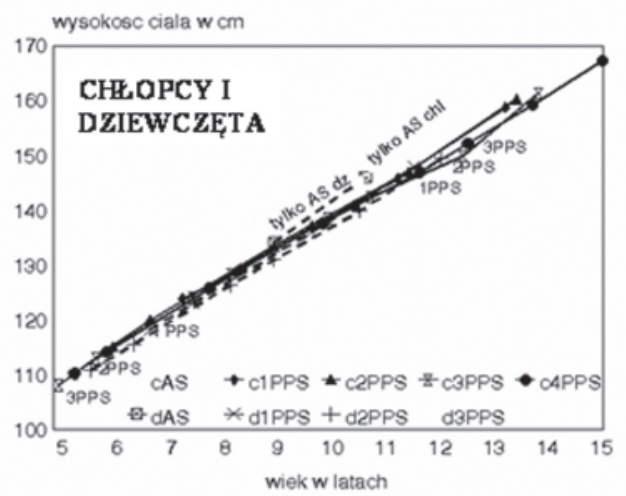

Rycina 8. Wykres szlaków rozwoju dla kohort chłopców, u których występuje tylko skok pokwitaniowy i po kilka skoków pzzed tym okresem (A) oraz to samo zjawisko dla chłopców i

dziewcząt (B) na podstawie danych Bocka (2004, tabela 2 i 3). Oznaczeria: $A S=$ skok pokwitaniowy, $1 \mathrm{PPS}=$ jeden skok przed pokwitaniem, $2 \mathrm{PPS}=$ dwa skoki, 3PPS = trzy skoki, 4PPS = cztery skoki; przed powyższymi oznaczeniami symbol c = chlopcy, $d=$ dziewczęta.

Przegląd sposobów odwzorcowania krzywych rozwoju przedstawił Pineau (1965), a ostatnio znakomite, w części krytyczne, omówienie istoty takiego postępowania opisała Karczmarek (2001) wskazując, że z pośród blisko dwustu podanych w literaturze sposobów na opisanie krzywych rozwoju wyróżnić można dwie tendencje. Pierwsza z nich zwana strukturalną wyznacza formalny model procesu wzrastania, druga zwana niestrukturalną stara się opisać empirycznie uzyskaną krzywą rozwoju. 


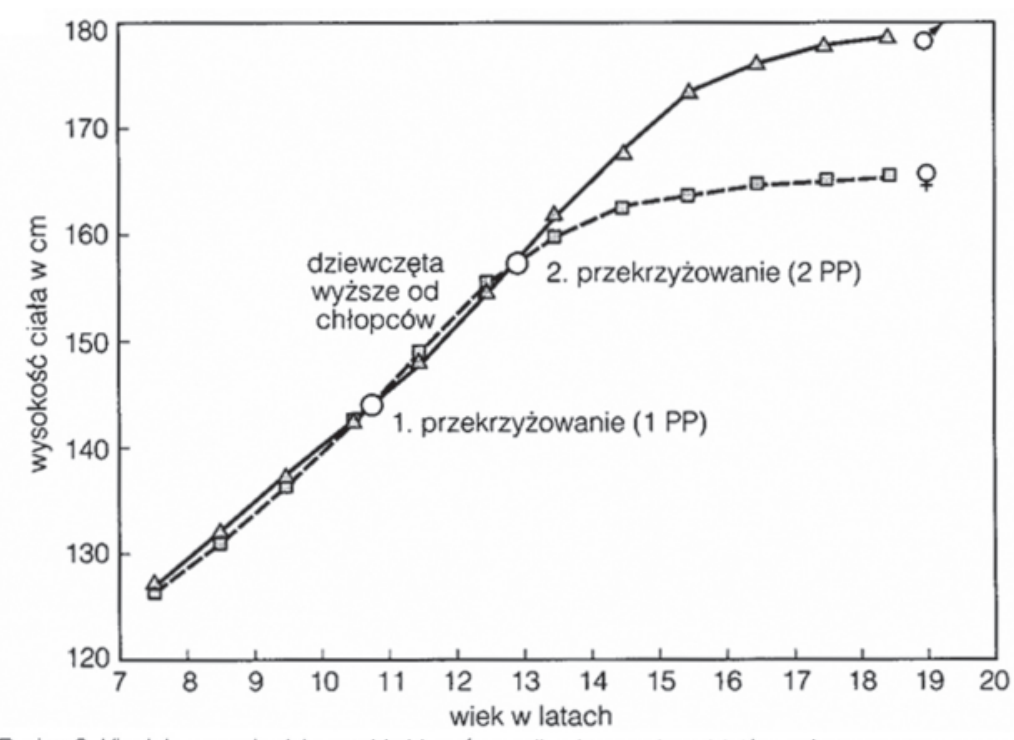

Rycina 9. Kinetyka rozwoju dziewcząt i chłopców według losowych matriałów ogólnopolskich z roku 1999 (dane Przewędy).

\section{Współczesne badania skokowych przyrostów wysokości ciała}

Wprowadzenie matematycznych metod wyrównujących krzywe rozwojowe doprowadziło do zaniechania badań nad nierównomiernością tempa rozwoju. Nie jest pewne, czy owe wyrównane krzywe oddawały genetycznie zdeterminowaną dynamikę procesu wzrastania, a takie być może było oczekiwanie twórców tych metod. Drugim uzasadnieniem byłoby wyrównywanie załamań spowodowanych błędami pomiarowymi, bądź w przypadku badań przekrojowych, nielosowości lub niedostatecznej liczby osób w pobranych próbkach.

W pewnym okresie (lata 1960-90) doszło do tego, że odrzucano zgłoszone do druku prace, gdy nie zastosowano do nich procedur wyrównywania krzywych (jak się potem okazało nie tylko uproszczonymi, ale i upraszczającymi istotę rozwoju) wzorami matematycznymi, lub wiek menarche nie obliczono probitami (choć można to było zastąpić medianą - co jednak wydłużało czas obserwacji do zakończenia dojrzewania wszystkich osobników w populacji). Tendencja do rzekomej „elegancji” metod stała się ważniejsza od odkrywczości danego artykułu. Przy stosowaniu owych wyrównań krzywych rozwoju powstawały tzw. reszty, wymykające się opisowi wynikającemu ze wzoru na krzywe rozwojowe. A dopiero ich analiza mogła wyjaśnić wpływy środowiska modyfikujące genetycznie zdeterminowany przebieg rozwoju, a więc kształtowanie się fenotypu poszczególnych dzieci. Analizie rejestrowanych już od XVIII wieku skokowych przyrostów 
w rozwoju (o czym wspominaliśmy na początku artykułu) poświęcono więcej uwagi dopiero w ostatniej dekadzie XX wieku, gdy rozpoczęto na większą skalę codzienne pomiary wzrastania (Hermanussen, Lampl, Caino i inni).

Obecne analizy oparte są na kilku seriach badań longitudinalnych, dokonywanych zazwyczaj co pół roku. Są to: (1) Fels Longitudinal Study z Ohio (USA) wykonywane u dużej grupy dzieci, z których do współczesnych analiz wybrano kompletne dane dotyczące 167 chłopców i 152 dziewcząt w wieku od 3 do 18 lat, a rozpoczęte jeszcze w 1929 roku (Bock i Tissen 1980, Roche 1992, Bock 2004), (2) Berkeley Guidance Study z Kalifornii (USA) wykonywane u 43 chłopców i 50 dziewcząt urodzonych w latach 1928-29 (Tuddenham i Snyder 1954), (3) Zurich Longitudinal Growth Study (Szwajcaria) w latach 1954-76 u 120 chłopców i 122 dziewcząt (Falkner 1960, Molinari i wsp. 1980, Gasser i wsp. 1984-1991, Ramsay i wsp. 1995) oraz (4) Edinburgh Longitudinal Growth Study w Szkocji (Wielka Brytania) u 80 chłopców i 55 dziewcząt urodzonych między 1972 i 1976 rokiem i badanych do okresu dojrzewania (Ratcliffe i wsp. 1986, Butler i wsp. 1990).

Butler uznawał za występowanie skoku, gdy miały miejsce 2 lub więcej kolejne zwiększone (acceleration) półroczne przyrosty wysokości ciała, po okresie spowolnionego wzrastania i gdy różnice, między maksymalnymi i poprzedzającymi je minimalnymi przyrostami przekraczały wielkość 2 błędów standartowych różnicy, która wynosiła $0,56 \mathrm{~cm}$ na rok.

Przy analizie danych z Ohio zaobserwowano (tab. 3), że skokowe przyrosty wysokości ciała przed okresem pokwitania (w tej sytuacji niesłusznie zwane prepubertal) występują u ponad 95\% dzieci. Jedynie u 3-5\% badanych (częściej u dziewcząt) nie występują przed pokwitaniowe skoki wysokości ciała. Najczęściej występują u obu płci (obok AS) dwa skoki przed pokwitaniem (PPS), na drugim miejscu - u chłopców trzy, u dziewcząt - jeden. Natomiast 4 PPS występują u 7\% chłopców i jedynie u 1\% dziewcząt.

Tabela 3. Częstość braku przed pokwitaniem skokowego przyrostu wysokości ciała oraz częstość występowania kilku skoków przed pokwitaniem (dane Bocka 2004). Wyttuszczono zjawisko występujące najczęściej, podkreślono drugie z kolei pod względem częstości.

\begin{tabular}{|c|c|c|}
\hline Skokowe przyrosty wysokości ciała & Chłopcy & Dziewczęta \\
\hline Brak PPS, jedynie skok pokwitaniowy (adolescent spurt - AS) & $3 \%$ & $5 \%$ \\
\hline Jeden skok przed pokwitaniem (pre pubertal spurt - PPS) & $17 \%$ & $\underline{41 \%}$ \\
\hline Dwa PPS & $\mathbf{3 9 \%}$ & $\mathbf{4 4 \%}$ \\
\hline Trzy PPS & $\underline{34 \%}$ & $8 \%$ \\
\hline Cztery PPS & $7 \%$ & $1 \%$ \\
\hline
\end{tabular}

Wyraźny jest związek ilości skoków wysokości ciała przed pokwitaniem (PPS) z ich wielkością oraz czasem trwania odstępów między kolejnymi skokami (Bock 2004). Wielkość pierwszego PSS oraz skoku pokwitaniowego jest 
większa u chłopców, podczas gdy drugiego i trzeciego PPS u dziewcząt. Przy tym przy mniejszej ilości skoków przed pokwitaniem, skok pokwitaniowy (AS) jest większy. Także różnica tempa wzrastania w roku maksimum skoku i w roku poprzedzającym (a więc przyspieszenie wzrastania) jest większa u chłopców (tab. 4). Istotne jest przy tym, że im więcej jest skoków przed pokwitaniem, tym wcześniejszy jest początek serii skoków i późniejszy skok ostatni (por. rys. 8), a więc okres przyspieszonego wzrastania odbywa się w dłuższym czasie.

Tabela 4. Wielkość poszczególnych skokowych przyrostów wysokości ciała u chłopców i dziewcząt $z$ dwoma i trzema skokami przed pokwitaniem, przy skoku pokwitaniowym w nawiasie podano różnicę tempa wzrastania $w$ roku poprzedzającym skok $i$ w roku maksimum skoku), wielkości podano w cm na rok (dane Bocka 2004). Podkreślono wielkości większe u danej płci.

\begin{tabular}{|c|c|c|c|c|}
\hline Rodzaj skoków & Chłopcy 3PPS & Chłopcy 2PPS & Dziewczęta 3PPS & Dziewczęta 2PPS \\
\hline 1-szy skok & $\underline{6,97 \mathrm{~cm} / \mathrm{rok}}$ & $\underline{6,64 \mathrm{~cm} / \mathrm{rok}}$ & $6,84 \mathrm{~cm} / \mathrm{rok}$ & $6,51 \mathrm{~cm} / \mathrm{rok}$ \\
\hline 2.gi skok & $6,17 \mathrm{~cm} / \mathrm{rok}$ & $5,75 \mathrm{~cm} / \mathrm{rok}$ & $\underline{6,22 \mathrm{~cm} / \mathrm{rok}}$ & $\underline{5,97 \mathrm{~cm} / \mathrm{rok}}$ \\
\hline 3-ci skok & $5,50 \mathrm{~cm} / \mathrm{rok}$ & & $\underline{5,91 \mathrm{~cm} / \mathrm{rok}}$ & \\
\hline S. pokwitaniowy & $\underline{9,06(4,07) \mathrm{cm} / \mathrm{r}}$ & $\frac{9,31(4,47)}{\underline{\mathrm{cm} / \mathrm{r}}}$ & $7,30(1,60) \mathrm{cm} / \mathrm{r}$ & $7,79(2,45) \mathrm{cm} / \mathrm{r}$ \\
\hline
\end{tabular}

W badaniach szkockich wyróżniono trzy skokowe przyrosty w dzieciństwie (Butler i wsp. 1990) nazywając je wczesny (przedszkolny), średni i późny, oraz jeden skok przedpokwitaniowy (przedpubertalny) (tab. 4). Przyrosty roczne w czasie skoku średniego i późnego dzieciństwa nie różnią się między chłopcami i dziewczętami, a ich tempo waha się między 5 a $6,5 \mathrm{~cm} /$ rok, odmienny jest zaś u obu płci skok przedszkolny (tab. 5). Gdy średni skok w dzieciństwie przyjmiemy za punkt zerowy, krzywa pozostałych skoków staje się podobna dla chłopców i dziewcząt (Butler i wsp. 1990, ryc. 10). Podobne badania wykonywano co pół roku od 4,5 do 19 lat życia u 181 chłopcach i 176 dziewczętach (wyjściowa liczba była trzykrotnie większa) w Poznaniu. W identycznym wieku podane jest występowanie skoku przedpokwitaniowego dla Edynburga i Poznania.

W badaniach $\mathrm{z}$ Ohio $\mathrm{w}$ całej próbce średni wiek występowania skoku pokwitaniowego (AS) wyniósł dla dziewcząt 11,5 roku, a dla chłopców 13,6 roku, a więc u tych ostatnich średnio 2,1 lat później (Bock 2004). O ile skok przedpokwitaniowy nie występował - skok pokwitaniowy miał miejsce u chłopców 1,8 roku później aniżeli u dziewcząt. Wraz ze zwiększaniem się ilości skoków przed pokwitaniem różnica wieku ich występowania ulegała zmniejszeniu. W przypadku występowania 4 skoków przed pokwitaniem różnica wieku występowania skoku pokwitaniowego wynosiła jedynie 0,93 roku. 
Tabela 5. Wiek występowania skokowych przyrostów wysokości ciała oraz procent osobników, u jakich dany skok wystapit w badaniach szkockich (Butler 1990) oraz powyższe skoki i skok pokwitaniowy w badaniach poznańskich (Kaczmarek 2001). Wielkość skoków podano $w \mathrm{~cm}$ na rok.

\begin{tabular}{|c|c|c|c|c|c|c|}
\hline Płeć & \multicolumn{3}{|c|}{ Chłopcy } & \multicolumn{3}{|c|}{ Dziewczęta } \\
\hline Rodzaj skoku & $\begin{array}{c}\text { Wiek } \\
\text { w latach }\end{array}$ & $\%$ & $\begin{array}{l}\text { Przyrost/ } \\
\text { rok }\end{array}$ & $\begin{array}{c}\text { Wiek } \\
\text { w latach }\end{array}$ & $\%$ & $\begin{array}{c}\text { Przyrost/ } \\
\text { rok }\end{array}$ \\
\hline \multicolumn{7}{|c|}{ Edynburg - Butler i wsp. 1990} \\
\hline $\begin{array}{l}\text { Przedszkolny (wczesnego } \\
\text { Dzieciństwa (EC) }\end{array}$ & 4,77 & $92,5 \%$ & $7,35 \mathrm{~cm}$ & 4,58 & $81,8 \%$ & $7,68 \mathrm{~cm}$ \\
\hline Średniego dzieciństwa (MC) & 7,03 & $100 \%$ & $6,71 \mathrm{~cm}$ & 6,66 & $98,2 \%$ & $6,83 \mathrm{~cm}$ \\
\hline Późnego dzieciństwa (LC) & 9,23 & $96,3 \%$ & $5,98 \mathrm{~cm}$ & 8,62 & $80 \%$ & $6,19 \mathrm{~cm}$ \\
\hline Przedpokwitaniowy (PPS) & 10,81 & $52,5 \%$ & $5,53 \mathrm{~cm}$ & 10,00 & $25,5 \%$ & $5,86 \mathrm{~cm}$ \\
\hline \multicolumn{7}{|c|}{ Poznań - Kaczmarek 2001} \\
\hline $\begin{array}{l}\text { Przedszkolny (wczesnego } \\
\text { dzieciństwa (EC) }\end{array}$ & 5,63 & $13,8 \%$ & $6,62 \mathrm{~cm}$ & 4,70 & $0,2 \%$ & $5,03 \mathrm{~cm}$ \\
\hline Średniego dzieciństwa (MC) & 6,60 & $55,2 \%$ & & 6,22 & $19,3 \%$ & \\
\hline Późnego dzieciństwa (LC) & 8,71 & $87,3 \%$ & & 8,14 & $67,0 \%$ & \\
\hline Przedpokwitaniowy (PPS) & 10,80 & & & 10,00 & & \\
\hline Pokwitaniowy (AS) & 13,88 & & & 11,79 & & \\
\hline
\end{tabular}

Ponieważ występowanie większej liczby skoków jest właściwe dla chłopców, występowanie tego zjawiska u dziewcząt zmniejsza różnicę między nimi i chłopcami pod względem wieku. Natomiast zarówno u chłopców jak i u dziewcząt skok pokwitaniowy był tym późniejszy, im więcej występowało skoków przed pokwitaniem (tab. 6).

Tabela 6. Wiek występowania skoku pokwitaniowego (AS) przy danej liczbie skoków przed pokwitaniem (PPS) oraz różnica wieku między chłopcami i dziewczętami (dane Bocka 2004). Wytłuszczono najpóźniejsze występowanie skoku pokwitaniowego

\begin{tabular}{|l|c|c|c|}
\hline \multirow{2}{*}{ Liczba PPS } & \multicolumn{2}{|c|}{ Wiek wystąpienia AS } & \multirow{2}{*}{$\begin{array}{c}\text { Różnica wieku } \\
\text { między płciami }\end{array}$} \\
\cline { 2 - 3 } & u chłopców & u dziewcząt & 1,82 \\
\hline \multicolumn{1}{|c|}{ Brak } & 12,41 & 10,59 & 1,74 \\
\hline 1-go skoku przedpokwitaniowy & 13,21 & 11,47 & 1,41 \\
\hline 2-ch skoków przedpokwitaniowych & 13,39 & 11,98 & 1,31 \\
\hline 3-ch skoków przedpokwitaniowych & 13,85 & 12,54 & 0,93 \\
\hline 4-ch skoków przedpokwitaniowych & $\mathbf{1 4 , 9 7}$ & $\mathbf{1 4 , 0 4}$ & \\
\hline Różnica wieku przy różnej liczbie skoków & 2,56 & 3,45 & \\
\hline
\end{tabular}

Bock (2004) sądzi, że PPS występują w przypadkowym czasie i nie wiążą się z konkretnymi zjawiskami w rozwoju jak aktywacja androgenów kory nadnerczy (adrenarche) czy tym podobnymi przyczynami. Przypuszczalnie występowania skoków przed pokwitaniem oraz ich liczba zależy od czynników środowiskowych i nie jest uwarunkowana genetycznie, co potwierdzają obserwacje trojaczków. 
Skok pokwitaniowy miałby według przekrojowych badań warszawskich z końca lat 1950-tych występować przeciętnie między 11 a 12 rokiem u dziewcząt i 13 a 14 rokiem u chłopców (Wolański 1962a). W cytowanych powyżej longitudinalnych badaniach w Ohio (Bock 2004) średni wiek występowania szczytu skoku pokwitaniowego miał miejsce w wieku 11,5 roku u dziewcząt i 13,6 roku u chłopców. Zapewne zbieżność wieku występowania jest przypadkowa, bowiem okres przewyższenia wysokości ciała dziewcząt ponad wysokość chłopów wykazuje tendencję przemian (ryc. 10 - Wolański 2005).

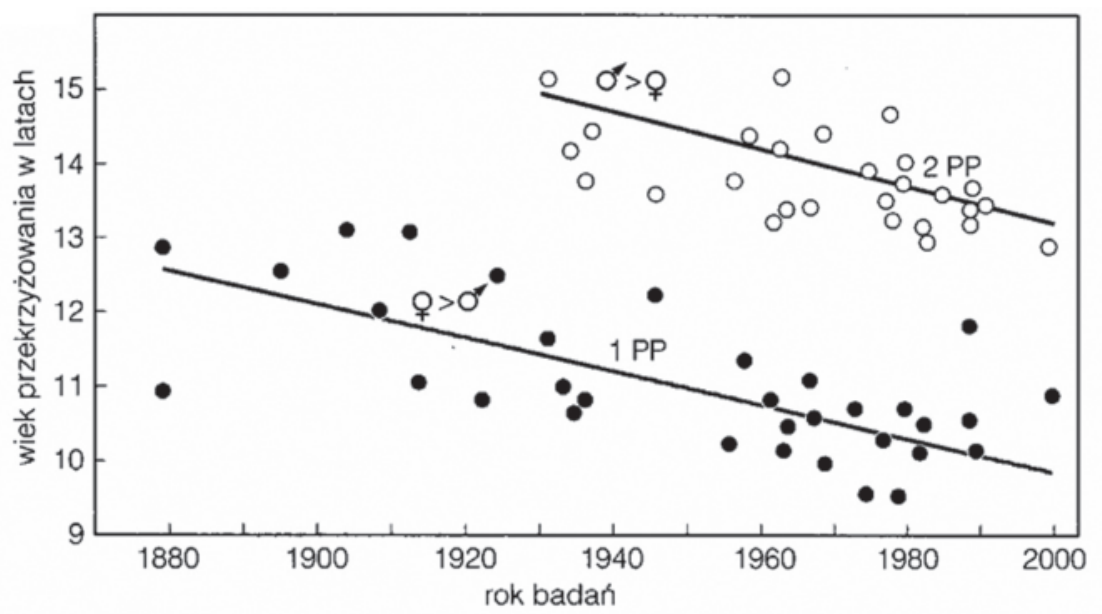

Rycina 10. Tendencja przemian wieku w jakim występuje pokwitaniowe przewyższenie wysokości ciała dziewcząt nad chłopcami (przekrzyżowanie 1) i ponowne przewyższenie wysokości dziewcząt przez chłopców (przekrzyżowanie 2) - por. ryc. 9 (Wolański, 2005).

W badaniach nad okresem pokwitania Caino i wsp. (2004) stwierdzili występowanie kilku okresów zahamowanego wzrastania trwających od 7 do 21 dni, które dzieliły krótkotrwałe skokowe przyrosty. Średnia trwania okresów skokowych przyrostów trwała $39 \%$ czasu obserwacji (u poszczególnych dziewcząt od 17 do 53\%), a wielkość tych skoków stanowiła 30\% (15-43\%) przyrostu wysokości ciała w badanych okresie. Maksymalny przyrost roczny wynosił 6,7 do 13,0 $\mathrm{cm}$, a największy obserwowany dzienny przyrost wyniósł 0,54 cm.

W badaniach skoku pokwitaniowego Lampl i Johnson (1993) w ciągu 389 dni stwierdzili jedynie 12 skokowych jednodniowych przyrostów, a jedna z przerw we wzrastaniu trwała nawet $100 \mathrm{dni}$. $\mathrm{W}$ okresie skoku pokwitaniowego przyrost wysokości ciała wyniósł $11 \mathrm{~cm}$ w ciągu roku, a w następnym już tylko $6,7 \mathrm{~cm}$. Jeden $\mathrm{z}$ dojrzewających chłopców przyrósł w ciągu doby aż $1,5 \mathrm{~cm}$. Skoki zdaniem Lampl odpowiedzialne są za 100\% przyrostów wysokości ciała.

Caino nie stwierdziła występowania żadnych regularnych rytmów ani cyklicznych zmian odnośnie mini-skokowych przyrostów i braku takowych, bądź występowania okresów "normalnego" tempa wzrastania. Pulsacyjny rytm rozwoju potwierdza Greco i wsp. (1990, 1994). 
W badaniach poznańskich stwierdzono zaskakujące zjawisko, że najwcześniej skok pokwitaniowy występuje w niskiej warstwie społeczno-ekonomicznej (SE), najpóźniejszy (u chłopców zresztą jedynie o 0,2-0,3 roku, u dziewcząt różnica jest nieistotna) w najwyższej warstwie SE. Jednak chłopcy z tej ostatniej warstwy są przy końcu wzrastania najwyżsi. A więc występuje tu prawidłowość, że to długość czasu wzrastania powoduje większą „dorosłą” wysokość.

Istnieje trudność $\mathrm{z}$ wyodrębnieniem początku skoku pokwitaniowego wobec istnienia wielu przyspieszeń rozwoju (mini-skoków). W badaniach poznańskich skok pokwitaniowy rozpoczęto obliczać od minimalnego przyrostu w całym okresie przedpokwitaniowym, który wynosi $5,21 \mathrm{~cm} /$ rok i występuje u dziewcząt w wieku 8,89 lat oraz 4,76 cm/rok u chłopców w wieku 10,78 lat. Szczyt maksymalnego przyrostu rocznego u dziewcząt $(\mathrm{PHV}=7,42 \mathrm{~cm} / \mathrm{rok})$ ma miejsce w wieku 11,79 lat, a u chłopców zjawisko to $(\mathrm{PHV}=9,35 \mathrm{~cm} / \mathrm{rok}$ ) występuje w wieku 13,88 lat (Kaczmarek 2001). Czas trwania przyspieszonego wzrastania od jego początku do szczytu skoku oszacowano na 2,9 lat u dziewcząt, a 3,2 lat u chłopców. Całkowity przyrost pokwitaniowy od jego początku do zakończenia wzrastania wynosi u dziewcząt $33,01 \mathrm{~cm}$, a u chłopców $36,09 \mathrm{~cm}$,

W badaniach pięciorga japońskiego rodzeństwa początek skoku pokwitaniowego oznaczano na podstawie dobowej zbiórki moczu i oceny wydzielania hydroksyproliny, kreatyniny oraz mocznika. W ten sposób oznaczony czas między początkiem skoku pokwitaniowego a wystąpieniem menarche u dwóch japońskich dziewczynek trwał u jednej z nich 28, a u drugiej 36 miesięcy (ryc. 11). W tym czasie przyrost wysokości ciała wyniósł odpowiednio 15,0 i $16,3 \mathrm{~cm}$, a masy 9,7 i 11,3 kg. Natomiast cały przyrost wysokości ciała w czasie skoku pokwitaniowego wyniósł 21,2 i 22,8 cm (Togo i Togo 1982, 1984, 1988).

Wystąpienie menarche badacze japońscy wiążą bardziej z przyspieszeniem przybierania masy ciała, aniżeli ze skokiem jego wysokości. Odmienne zdanie wyraża Kaczmarek (2001) na podstawie badań poznańskich, sądzi ona, że menarche jest ściśle związane z wiekiem szczytu skoku pokwitaniowego wysokości ciała, i u „znakomitej większości” dziewcząt menarche występuje po szczycie skoku pokwitaniowego, chociaż u 3,4\% dziewcząt poznańskich pierwsza miesiączka wystąpiła w trakcie skoku pokwitaniowego, lub przed nim. Dla całości dziewcząt z badań poznańskich wiek szczytu skoku pokwitaniowego wysokości ciała wynosił 11,58 lat, dla masy ciała 12,50 lat, a wiek wystąpienia menarche 12,86 lat. To zjawisko obserwowaliśmy także w comiesięcznych badaniach na Jukatanie w Meksyku (wiele dziewcząt wykazywało przyrosty po wystąpieniu menarche, a np. podana tam dziewczyna nr 65 wykazywała po menarche jeszcze znaczne skokowe przyrosty wysokości ciała - Wolański i wsp. 2004). W badaniach przekrojowych stwierdzono, że menarche występuje u dziewcząt miejskich w wieku 12,8 lat, to jest 1,3 lat po szczycie skoku pokwitaniowego wysokości ciała, mającym miejsce w wieku 11,5 lat, podczas gdy u dziewcząt wiejskich - w wieku 15,9 

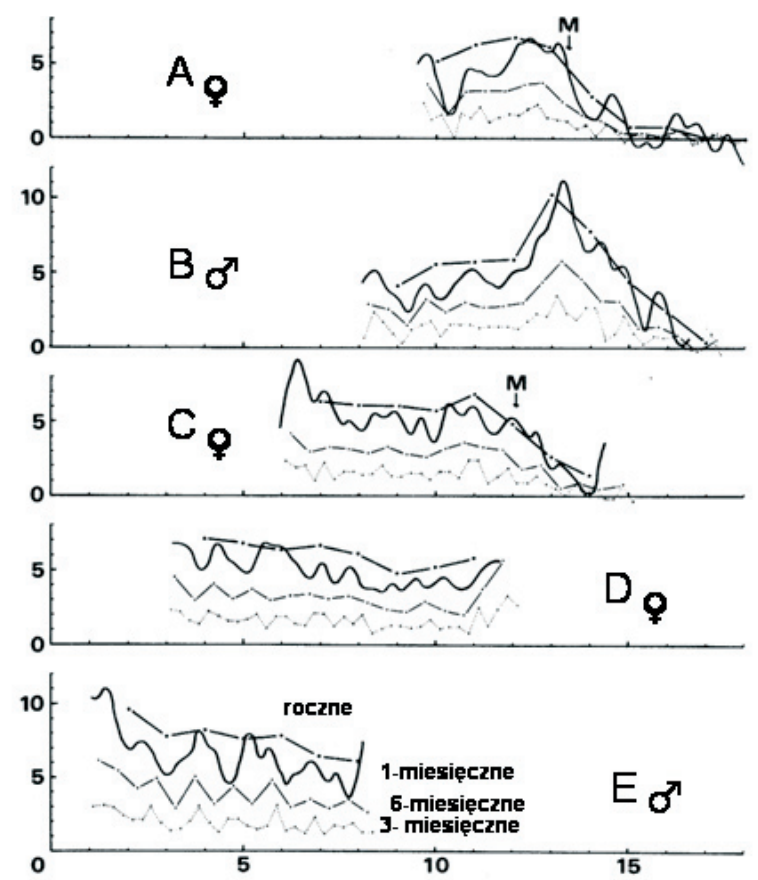

Rycina 11. Przyrosty wysokości ciała pięciorga dzieci japońskich. Podano rejestracje skoków zależnie od przyjętego podziału między kolejnymi badaniami: $\mathrm{w}$ mm dla przedziału miesięcznego oraz $\mathrm{w} \mathrm{cm}$ dla przedziałów 3 , 6 i 12 miesięcznych (Togo i Togo, 1984); $M$ = menarche

lat to jest 2,4 lat po szczycie skoku pokwitaniowego (13,5 lat) (Wolański 1964). Potwierdzało to wyniki Simmonsa i Greulicha (1943), że gdy wcześniejszy jest skok pokwitaniowy, krótszy jest też czas dzielący go od wystąpienia menarche. Przypuszczalnie dynamika (liczba i wielkość skoków oraz czas ich występowania) tempa wzrastania zależy od bilansu energetycznego (dostępnej energii i sposobu jej wykorzystania w latach pokwitania).

Z kolei w badaniach nad skokiem pokwitaniowych stwierdzono, że bywa on w różnych populacjach i grupach etnicznych zróżnicowany nie tylko co do wieku w jakim występuje, ale także co do czasu trwania (Artaria 2001, Siniarska i Zielińska 2002, Zielińska 2002). W populacjach europejskich oraz u Meksykan pochodzenia europejskiego (Kreoli) skok trwał 2-3 lata, a w populacjach afrykańskich i azjatyckich oraz u Indian Maja do 5 lat. Ponieważ średnio wynosi on 20-25 cm, ale trwa od 2 do 5 lat, wskazuje to na jego odmienne tempo. W świetle omawianych wcześniej wyników badań krakowskich (por. ryc. 6), gdzie skok był bardziej intensywny i trwał 2-3 lata dla poszczególnych grup o różnym wieku jego wystąpienia, a był niższy, bardziej płaski i trwał 5 lat i dla wszystkich grup łącznie, można wysunąć przypuszczenie, że związane jest to z różnicami typologicznymi. Być może więc grupy autochtoniczne wykazują większe zróżnico- 
wanie wewnątrz pul genowych poszczególnych populacji. Wymaga to jednak odpowiednich badań.

Wypowiedziano ostatnio pogląd, że linie Harrisa (poziome zagęszczenia tkanki w kościach długicz) nie wynikają z zaburzeń żywieniowych lub chorobowych, lecz są objawem normalnie występujących w trakcie rozwoju skokowych (saltations) przyśpieszeń wzrastania (Alfonso i wsp. 2005).

\section{Co wiemy o neurohormonalnym sterowaniu wzrastaniem}

Dużo wiemy o przebiegu rozwoju, mniej o jego neurohormonalnych mechanizmach sterujących, jeszcze mniej o genetycznej determinacji (chociaż duży postęp wniosło odkrycie genów homeoboksowych), zaś całkiem niewiele (istnieją poważne luki) o czynnikach endogennych odpowiedzialnych za następstwo w czasie poszczególnych przejawów rozwoju, niekiedy zwane stadialnością rozwoju. Wykrycie rozmaitych sprzężeń zwrotnych (np. w postaci gonadostatu) dotyczy raczej mechanizmów wspomagających sterowanie, a nie nadrzędnej kontroli i uruchamiania kolejnych etapów. W niniejszym artykule wykazano, że wzrastanie nie odbywa się w tempie jednostajnym, lecz występują naprzemienne okresy przyrostów i pauzowania (stabilizacji). Powstaje pytanie, jaki jest tego mechanizm.

Ogólny proces rozwoju osobniczego (przebieg ontogenezy) jest uwarunkowany i koordynowany genetycznie. Geny zawierają jednak jedynie informację jak ma przebiegać proces tworzenia nowych komórek oraz w jakim tempie i kolejności. Informacja ta została wyselekcjonowana w procesie rozwoju rodowego (przebiegu filogenezy) naszego gatunku. Do dziś dnia proces ten nie jest w pełni rozpoznany, dlatego też nie potrafimy kierować rozwojem i odwracać jego genetycznie uwarunkowanych odchyleń, w tym wpływu na działaność neurohormonalną mózgu, nadrzędną w stosunku do funkcji poszczególnych gruczołów i tkanek. Współcześnie wiemy natomiast, że sposób żywienia (konkretnie dostarczanie, a w szczególności brak niektórych związków chemicznych w pokarmie) wpływa na ekspresję genów. Obrazowo mówiąc, nie tylko budowla (soma) potrzebuje budulca, ale i architekt oraz murarz potrzebuje pokarmu (geny energii dla kodowania aminokwasów i substratu dla powielania się).

Zasadniczą rolę w kontroli wzrastania odgrywa hormon wzrostu (GH) oraz insulinopodobne czynniki wzrastania (IGF), wydzielane przez różne tkanki organizmu. Hormon wzrostu jest tym specyficzny, że wydzielany jest względnie systematycznie (to jest nie na konkretny bodziec pobudzający) i ma to miejsce wielokrotnie w ciągu doby, najintensywniej w ciągu 60 - 120 minut po zaśnięciu, po wysiłku fizycznym i w czasie niepokoju przez 30 - 60 minut. W tym ostatnim przypadku zależnie od siły bodźca może mieć przeciwstawne skutki dla przebiegu rozwoju i wzrastania. 
Działanie GH jest dość złożone. We wczesnej fazie jego działania potęguje przyswajanie aminokwasów i glukozy przez mięśnie i tkankę tłuszczową - przypuszczalnie przez zwiększenie przepuszczalności błon komórkowych, być może jako bezpośrednie współdziałanie hormonu i receptorów błony. Zaobserwowano jednak, że niektóre efekty działania GH są opóźnione, dotyczy to przyswajania i utleniania glukozy, wbudowywania aminokwasów do peptydów, wzrostu mobilizacji kwasów tłuszczowych i wtórnego wzrostu wydzielania insuliny. Opóźniony efekt jest wywołany przez czas potrzebny dla ogniwa pośredniego, syntetyzowania w wątrobie, mięśniach i nerkach insulinopodobnych czynników wzrostu (IGFs - somatomedyn). Skutki opisanych działań mogą jednak być odmienne zależnie od podaży pokarmu i pozyskanych z niego substancji budulcowych oraz energii.

Somatomedyny są peptydami odpowiedzialnymi za syntezę DNA, RNA i białka w chrząstce i przypuszczalnie w mięśniu, aktywizują one transport glukozy i aminokwasów oraz utlenianie glukozy i syntezę tłuszczów, wreszcie wbudowywanie siarki do substancji chrząstki. Poziom somatomedyn wzrasta po każdorazowym impulsie GH. Poziom ten zwiększa się także od urodzenia do pokwitania, zwiększa się także, gdy tempo wzrastania maleje. Nie występuje, więc prosta zależność między ich wydzielaniem a intensywnością procesów rozwojowych.

Działanie na procesy wzrastania jest kilkustopniowe (kaskadowe): podwzgórzowa somatoliberyna (GHRH) stymuluje przysadkę do wydzielania GH, który oddziałuje na komórki bezpośrednio oraz poprzez krwioobieg stymuluje szereg tkanek do wydzielania somatomedyn (IGF), które z kolei na drodze autokrynowej i parakrynowej wpływają na podziały komórkowe.

Oddziaływanie bezpośrednie GH i pośrednie przez IGF ma miejsce na różnych etapach różnicowania i podziału komórek (tzw. dual effector system). $\mathrm{Z}$ drugiej strony podwzgórze produkuje także somatostatynę (hormon hamujący hormon wzrostu - GHRIH).

GHRH i GHRIH są w pewnym stopniu antagonistami i ich wydzielanie jest ze sobą ujemnie skorelowane, a aktywność naprzemiennie cykliczna (pulsacyjna).

Niemal wszystkie komórki ciała mają specjalne receptory wrażliwe na stymulację hormonu wzrostu $(\mathrm{GH})$, co powoduje wydzielanie przez wiele z nich somatomedyn (IGFs) i z kolei oddziałuje na wzrastanie kości długich i tkanek miękkich oraz wpływa na aktywność insuliny i metabolizm tłuszczów. Pulsacyjna zmiana stężenia GHRH względem GHRIH raczej, niż częstości, wpływa na nierównomierność tempa wzrastania.

Być może od pulsacyjnych zmian stężenia GHRH/GHRIH oraz wspomnianego podwójnego efektu zależą dzienne przyrosty kości, w wyniku czego proces wzrastania nie jest jednostajny, lecz składa się z kilkunastodniowych okresów stagnacji (stasis) i jednodobowych przyspieszeń (saltations - mini-growth-spurts). Jest to przypuszczalnie proces neurohormonalnie synchronizowany na poziomie organizmu, a obejmujący zespoły komórek. 


\section{Co należy wyjaśnić}

Ciągle nie jest jasne: (1) czy akumulacja tkanki tłuszczowej przed okresem pokwitania jest związana ze zjawiskiem petnienia i jest zjawiskiem konkurencyjnym w stosunku do procesów bujania; (2) czy i jaki wpływ ma wiek występowania i intensywność skoku pokwitaniowego na dorosła wysokość ciała; (3) czy zróżnicowanie czasu trwania skoku pokwitaniowego dotyczy ogólnie innego tempa wzrastania, czy też przerw w czasie pokwitaniowego przyspieszenia wzrastania, (4) czy skok pokwitaniowy w ramach populacji bardziej jednorodnej genetycznie jest intensywniejszy i trwa krócej, aniżeli w populacji zróżnicowanej genetycznie, (5) czy też charakter skoku pokwitaniowego zależy od stopnia zaawansowania cywilizacyjnego, zamożności, trybu życia i warunków bytowych.

Należy zweryfikować przypuszczenia: (1) że mniejsza liczba skoków przedpokwitaniowych powoduje pewną akumulację sił witalnych i wcześniejsze wystąpienie skoku pokwitaniowego (AS), a więc energia zużyta na kolejne skoki przedpokwitaniowe opóźnia wystąpienie skoku pokwitaniowego, a być może i ogólnie opóźnia pokwitanie; (2) że wydłużenie okresu rozwoju wymaga mniejszych nakładów energetycznych na jednostkę czasu, w szczególności czy występuje to przy niedoborach pokarmowych.

Natomiast wydaje się wyjaśnione to, co sformułujemy poniżej we wnioskach.

\section{Wnioski}

1. W całej ontogenezie istnieją okresy szybszego i zwolnionego tempa wzrastania i są one specyficzne dla poszczególnych komponentów ciała (wysokości, masy, w tym odmienne dla tkanki tłuszczowej niż pozostałej masy).

2. Naprzemian istnieją okresy przyspieszonego wzrastania przedzielone dłuższymi okresami powolnego wzrastania.

3. Liczba występujących skoków w okresie przed pokwitaniem (PPS) wpływa na czas ich pojawiania się, przy większej liczbie część występuje wcześniej, a część później niż przy występowaniu tylko jednego PPS. Ogólnie więc przy większej liczbie skoków dłużej trwa okres ich występowania.

4. Skok pokwitaniowy jest typową właściwością ontogenezy człowieka i obejmuje on przyspieszone wzrastanie kośćca i mięśni w niemal wszystkich częściach ciała.

5. Im skok pokwitaniowy występuje we wcześniejszym wieku u danej płci tym jest bardziej intensywny, jednak mimo iż u dziewcząt występuje wcześniej, aniżeli u chłopców bardziej intensywny jest u chłopców.

6. Im skok pokwitaniowy występuje u dziewcząt wcześniej, tym czas dzielący go od menarche jest krótszy.

7. Wiek wystąpienia skoku pokwitaniowego (AS) jest najwcześniejszy przy braku PPS, natomiast jest tym późniejszy im poprzedza go więcej PPS. 
W większości przypadków u chłopców (w 73\%) występuje dwa do trzech PPS, a u dziewcząt (w 85\%) jeden do dwóch PPS.

8. Genetycznie uwarunkowane zróżnicowanie wielkości ciała wzrasta w okresach, gdy włączają się mechanizmy kontroli neurohormonalnej przyspieszające proces rozwoju.

9. Analizowane badania potwierdzają wypowiadaną opinię, że zmiany tempa rozwoju są długookresowo (w sensie okresów ontogenezy) uwarunkowane endogennie, a doraźnie modyfikowane egzogennie.

\section{Piśmiennictwo}

Abel W., Die Erbanlagen des normalen Stutzgewebes. Handbuch der Erbbiologie des Menschen. Berlin 1940

ACHeson R.W., Dupertuis C.M., The relationship between physique and rate of skeletal maturation in boys. Human Biology, 29:167-193, 1957

Alfonso M.P., Thompson J.L., Standen V.G., Reevaluating Harris lines - A comparison between Harris lines and enamel hypoplasia. Collegium Antropologicum, 29 (2): 393-408, 2005.

Artaria M.D., Growth of Javanese children in Malang. W: Causes and effects of Human Variation, ed. by M. Henneberg, 2001, str. 139-155

BaCkman G., Das Wachstum der Körperlänge des Menschen. Kunglicke Svenska Verenskapsademiens Handlingar. Series 3, 14, 1, 1934

Barker R.G., Stone C.P., Physical development in relation to menarcheal age in university women. Human Biology, 8:198-222, 1936

BAYLEY N., Skeletal maturing in adolescence as a basis for determining percentage of completed growth. Child Developm., 14:1-46, 1943

Bergman P., Charzewska J., Kaczanowski K., Piechaczek H., (redaktorzy). Problemy taksonomii kopalnych form ludzkich i typologii współczesnego człowieka. Ósme warsztaty antropologiczne. AWF, Warszawa 2005

BIELICKI T., On the relationship between maturation rate and maximum velocity of growth during adolescence. Studies in Physical Anthropology, 3:79-84, 1976

Bielicki T., Hauspie R.C., On the independence of adult stature from the timing of the adolescent growth spurt. Amer. J. of Human Biology, 6:245-247, 1994

Bielicki T., Welon Z., Growth data as indicators of social inequalities; the case of Poland. Yearbook of Physical Anthropology, 25:153-167, 1982

BoAs F., Observation on the growth of children. Science, 72:44-48, 1930

Boas F., Studies in growth. Human Biology: 4:307-350, 1932, 5:429-444, 1933, 7:303-318, 1935

BocheŃsKa Z., Okresy pełnienia i bujania w świetle zmian tkanki tłuszczowej. Materiały i Prace Antropologiczne. 24, 1958 
Bocheńska Z., PANek S., Wzrastanie i rozwój dziewcząt krakowskich z uwzględnieniem cech typologicznych. Roczniki Naukowe WSWF, 5:117-143, 1966

Bock R.D., Multiple prepubertal growth spurts in children of the Fels Longitudinal Study: comparison with results from the Edinburgh Growth Study. Annals o Human Biology, 31(1):59-74, 2004

Bock R.D., Thissen D., Statistical problems of fitting individual growth curves. W „Human Physical Growth and Maturation: Methodologies and Factors”. Pod red. F.E. Johnsona. A.F. Roche'a i C.Susanne'a, Plenum Press, New York (str. 265-290), 1980

Bоск R.D., Thissen D., Du Toit S.H.C., AUXAL 3: Auxological analysis of longitudinal measurements of human stature. Scientific Software Intl., Chicago 1994

Bоотнвy E.J., Guy M.A., Davies T.A.L., The growth of adolescents. Mon. Bull. Minist. Health Lab.Serv., 11:208-223, 1952

BRZEZIŃski Z.J., Warunki społeczno-bytowe a rozwój somatyczny chłopców. Materiały i Prace Antropologiczne, 68. Zagadnienia Ontogenezy, I: 7-62, 1964

Butler G.E., McKie M., Ratcliffe S.G., The cyclical nature of prepubertal growth. Annals of Human Biology, 17(3):177-198, 1990

Caino S., Kelmansky D., Lejarraga H., Adamo P., Short-term growth at adolescence in healthy girls. Annals of Human Biology, 31(2):182-195, 2004

Deming J., Application of the Gompertz curve to the observer pattern of growth in length of 48 individual boys and girls during adolescent cycle of growth. Human Biology, 29:83-122, 1957

Falkner F., Child development. An international method of study. Modern Problems in Pediatrics. Karger, Basel 1960

Frisch R.E., Critical age at menarche, initiation of the adolescent growth spurt and control of puberty. W "Control of the onset of puberty”, pod red. M.M. Grumbach, G.D. Grace i F.F. Mayer, Willey, New York 1974, str. 403-423

Frisch R.E., Fatness and fertility. Scientific American, 258(3):88-95, 1988.

GARN S.M., The genetics of normal human growth. In "De Genetica Medica", II(1):415-434, ed. by L. Gedda. Inst. G. Mendel, Roma 1962

GARN S.M., Body size and its application. In "Child Development Research", II:529561, ed. by L.W. Hoffman, M.L. Hoffman. Russel Sage Found., New York 1966

Garn S.M., Clark D.C., Trends in fatness and the origin of obesity. Pediatrics, $87: 443-456,1976$

Gasser T., Kneip A., Binding A., Prader A., Molinari L., The dynamics of linear growth in distance, velocity and acceleration. Annals of Human Biology, 18(3):187-205, 1991a

Gasser T., Kneip A., Ziegler P., Largo R., Molinari L, Prader A., The dynamics of growth of width in distance, velocity and acceleration. Annals of Human Biology, 18(5):449-461, 1991b 
Gasser T., Kneip A., Ziegler P., Largo R., Prader A., A method for determining the dynamics and intensity of average growth. Annals of Human Biology, 17(6):459-474, 1990

Gasser T., Mueller H.G., Koeler W., Prader A., Largo R., Molinari L., An analysis of the mid-growth and adolescent spurts of height based on acceleration. Annals of Human Biology, 12:129-148, 1985

Gasser T., Koeler W., Mueller H.G., Kneip A., Largo R., Molinari L., PrAder A., Velocity and acceleration of height growth using kernel estimation. Annals of Human Biology, 11:1397-411, 1984

Gethner C., Satake T., Woynarowska B., Malina R., Adolescent spurts in body dimensions: average and modal sequences. Amer. J. of Human Biology, 11:287-295, 1999

Grabowska J., Genetic control of some properties in children's growth. Studies in Human Ecology, 1:167-181, 1973

GraY H., Individual growth rate from birth to maturity for 15 physical traits. Human Biology, 13:306-333, 1941

Greco L., Capasso A., De Frusco C., Paludetto R., Pulsative weight increase in very low birthweight babies appropriate for gestational age. Archives of Diseases of Childhood, 65:373-376, 1990

Greco L., Tipo V., Di Donato F., Mayer M., Pulsative growth pattern during catch-up growth in childhood coeliac disease. Acta Paediatrica, 83:724-729, 1994

Gryglaszewska-Puzynina M., Spostrzeżenia nad sprawnością fizyczną dziewcząt różnych typów rasowych. Przegląd Fizjologii Ruchu, 8(3-4):258-299, 1937

Healy M.J.R., Statistics of growth. W „Human growth”, pod red. F. Falknera i J. M. Tannera, Plenum Press, New York i Londyn 1978, str. 169-181

Harris H.A., Child health and development. London 1947

Hauspie R.C., Curve-fitting. W „The Cambridge Encyclopedia of Human Growth and Development. Pod red. S.J. Uljaszka, F.E. Johnstona i M.A. Preece’a, Cambridge Univ. Press, Cambridge 1998, str. 114-115

Hermanussen M., Geiger-Benoit K., No evidence for saltation in human growth. Annals of Human Biology, 22(4):341-345, 1995

Hermanussen M., Geiger-Benoit K., Burmeister J., Sippel W.G., Periodical changes of short term growth velocity ('mini growth spurts') in human growth. Annals of Human Biology, 15:103-109, 1988

Howe P.E., Schiller M., Growth responses of the school children to changes of diet and environmental factors. J.appl.Physiology, 5:51-61, 1952

Hulanicka B., Lipowicz A., Kozię S., Kowalisko A., Tempo dojrzewania i otłuszczenie w dzieciństwie a ryzyko chorób układu krążenia u 50 letnich mężczyzn i kobiet. W „XXV lat antropologii w IPCZD. Rola antropologii klinicznej w medycynie”, IPCZD, Warszawa 2005, str. 3 
Jaczewski A., Pyżuk M., Wstępne wyniki badań nad wiekiem dojrzewania dziewcząt i chłopców jednej ze szkół warszawskich. Prace i Materiały Naukowe IMD, 4:229-234, 1965

JASICKI B., Wzrastanie wymiarów głowy z wiekiem u młodzieży męskiej krakowskich szkół powszechnych i średnich. Część I, długość głowy; część II, szerokość głowy. Sprawozdania z posiedzeń TNW, Wydział IV, 27:39-42, 1934

JAsICKI B., W sprawie typów morfologicznych młodzieży krakowskiej od 15 do 19 roku życias. Sprawozdania Polskiej Akademii Umiejętności, 40(3):82-83, 1935

JASICKi B., Dynamika rozwojowa męskiej młodzieży szkolnej z Krakowa. PAU, Prace i Materiały Antropologiczne. T. 1, Kraków 1938a

JASICKI B., Czy na podstawie pomiarów wzrostu i wagi można wyróżnić tzw. okresy bujania i pełnienia w czasie wzrastania organizmu ludzkiego? Przegląd Antropologiczny 12(4):533-551, 1938b

JASICKI B., Dalsze badania nad dynamiką rozwojową młodzieży szkolnej. PAU, Prace i Materiały Antropologiczne. T. 2(2):57-93, Kraków 1948a

Jasicki B., Zjawisko dojrzewania a rozwój wysokości ciała chłopców. Przegląd Antropologiczny, 15:101-118, 1948b

JASICKI B., Kształtowanie się wymiarów i proporcji głowy z wiekiem u młodzieży krakowskiej. Zeszyty Naukowe UJ, Prace zoolog., 12:7-35, Kraków 1966

Jolicoeur P., Pontier J., Abidi H., Asymptotic models for longitudinal growth curve for human stature. American J. Human Biology, 4:461-468, 1992

Kaczmarek M., Poznańskie Badania Longitudinalne. Rozwój fizyczny chłopców i dziewcząt. Monografie Instytutu Antropologii UAM, nr 9, Poznań 2001

Kaczmarek M., Adolescent growth and its relation to menarche, Przeglad Antropologiczny. 65:27-42, 2002

Kaczmarek M., Zastosowanie funkcji potrójnie logistycznej z szeregami Fouriera $\mathrm{w}$ analizie reszt do wykreślenia krzywych wzrastania wysokości ciała. W "Metody statystyczne $w$ antropologii, 6 warsztaty antropologiczne", Wydawnictwo AWF, Warszawa 2003, str. 61-76

Karlberg J., Fryer J.G., Engstrom I., Karlberg P., Analysis of linear growth using mathematical model. II. From 3 to 21 years. Acta Paediatrica Scandinavica, Suppl. 337:12-29, 1987

KARlBerg J., A biologically-oriented mathematical model (ICP) for human growth. Acta Paediatrica Scandinavica, 350:70-94, 1989

Karlberg J.,The infancy-childhood growth spurt. Acta Paediatrica Scandinavica, 367:111-118, 1990

Karlberg J., The human growth curve. W „The Cambridge Encyclopedia of Human Growth and Development". Pod red. S.J. Uljaszka, F.E. Johnstona i M. A. Preece'a, Cambridge Univ. Press, Cambridge 1998, str. 108-114 
KARLBeRg J., JaliL F., LAM B., Low L., YeUnG C.Y., Linear growth retardation to the three phases of growth. European Journal of Clinical Nutrition, 48 (suppl. 1):S25-S44, 1994

KRALJ-ČerČeK L., The influence of food, body build, and social origin on the age at menarche. Human Biology, 28:393-406, 1956

LAMPL M., Further observations on diurnal variation in standing height. Annals of Human Biology, 19(1):87-90, 1992

LAmpl M., Johnson M.L., A case study of daily growth during adolescence: a single spurt or changes in the dynamics of saltatory growth? Annals of Human Biology, 20(6): 595-603, 1993

Lampl M., Veldhuis J.D., Johnson M.L., Saltation and stasis: A model of human growth. Science, 258:801-803, 1992

Largo R.H., Gasser T., Prader A., Stuetzle W., Huber P.J., Analysis of the adolescent growth spurt using smoothing spline functions. Annals of Human Biology, 5:421-434, 1978

LipIEC M., Über das Wachstum der polnische Judinen. Antropologische Geselschaft, Wien 1912

Marubini E., Mathematical handling of long-term longitudinal data. W" Human growth", pod red. F. Falknera i J.M. Tannera, Plenum Press, New York i Londyn 1978, str. 209-225

Meredith H. V., The rhythm of physical growth. University of Iowa Studies in Child Welfare. XI, 3, 1935

Meredith H. V., Boynton B., The transverse growth of the extremities: an analysis of girth measurements for arm, forearm, thigh and leg taken on Iowa City white children. Human Biology, 8:366-403, 1937

Molinari L., Largo R.H., Prader A., Analysis of growth spurt in age seven (mid-growth spurt). Helvetica Paediatrica Acta, 35:325-334, 1980

Mydlarski J., Sprawność fizyczna młodzieży w Polsce. Przeglad Fizjologii Ruchu. Warszawa 1934

Palmer C.E., Kawakami R., Reed L.J., Anthropometric studies of individual growth. II. Age, weight and rate of growth in weight, elementary school children. Child Development, 8:47-61, 1937

Pineau H., La croissance et ses lois. Laboratoire d'Anatomie, Faculte de Medicine, Paris 1965

Preece M.A., Baines M.J., A new family of mathematical models describing the human growth curve. Annals of Human Biology, 5:1-24, 1978

Preece M.A., Henrich I., Mathematical modeling of individual growth curves. British Medical Bulletin, 37:247-252, 1981

Pryor H.B., Certain physical and physiological aspects of adolescent development in girls. J.Pediatrics, 8:52-62, 1936

Pyżuk M. Cechy dojrzewania płciowego a rozrost i kształtowanie się proporcji między składnikami ciała. Prace i Materiały Naukowe IMD, 2:81-88, 1964 
Ramsay J.G., Bock R.D., Gasser T., Comparison of height acceleration curves in the Fels, Zurich, and Berkeley growth data. Annals of Human Biology, 22(5):413-426, 1995

Ratcliffe S.G., Murray L., Teague P., Edinburgh study of growth and development of children with sex chromosome abnormalities, III. W „Prospective studies in children with sex chromosome aneuploidy. Pod red. S.G, Radcliffe'a i N. Paula, March of Dimes Birth Defects Foundation. Original Articles Series. 22(3):73-118, 1986

Reynolds E.L., Wines J.V., Individual differences in physical changes associated with adolescence in girls. Amer. J. Dis. Childhood, 75:329-350, 1948

Roche A.F., Growth, maturation and body composition. The Fels Longitudinal Studies 1929-1991. Cambridge University Press, Cambridge 1992

Schreiber W., Badania nad antropologia dzieci Chrześcijańskich, Żydowskich $i$ Karaimskich $w$ Galicyi. Dodatek do Sprawozdań z posiedzeń Towarzystwa Naukowego Warszawskiego, Warszawa 1910

Shuttleworth F.K., Sexual maturation and the physical growth of girls age six to nineteen. Monographs of the Society for Research in Child Development, 2(5):253, 1937

Shuttleworth F. K., The physical and mental growth in boys and girls age six to nineteen in relation to age at maximum growth. Monographs of the Society for Research in Child Development, 4, 3, 1939

Shuttleworth F. K., The adolescent period: A graphic atlas. Monographs of the Society for Research in Child Development, 14, ser. 49, 1, 1949

Sikora P., Wpływ kierunków rozwoju osobniczego na różnicowanie się bałtoidów. Spraw. PAU, 50:435-437, 1949

Simons K., Greulich W.W., Menarcheal age and the height, weight and skeletal age of girls age 7 to 17 years. Journ. Pediatrics, 22:518-548, 1943

Siniarska A., Rojas A., Valentin G., Wolański N., Dickinson F., Czy istnieje sezonowy rytm rozwoju w warunkach tropikalnych? (Raport $1 \mathrm{z}$ dwuletnich comiesięcznych badań na Jukatanie w Meksyku). Studia Ecologiae et Bioethicae, 2:9-46, 2004

Siniarska A., Zielińska A., Ethnic differences in body build and maturation of 6-18 years old schoolgirls from Merida, Yucatan, Mexico. Collegium Antropologicum. 26, Supplement, 189-190, 2002

Spitzer-Willerowa O., Przyczynek do badań antropologicznych dziewczynek krakowskich. Mater. Antrop., Archeol. i Etnolog., 14:110-146, 1919

Stone C.P., BARKer R.G., On the relationship between menarcheal age and certain measurements of physique in girls of the ages 9 to 16 years. Human Biology, 9:1-28, 1937

Stratz C.H., Lebensalter und Geschlechter. Stuttgart 1926

Stützle W., Gasser T., Molinari L., Largo R.H., Prader A., Huber P.J., Shape invariant modeling of human growth. Annals of Human Biology, 7:507-528, 1980 
Talko-Hryncewicz J., Przyczynek do antropologii dzieci chrześcijańskich i żydowskich na Ukrainie. Materiały Komisji antropologii, archeologii i etnografii, Akademia Umiejętności, Kraków 1908

Thalange N.K.S., Foster P.J., Gill M.S., Price D.A., Clayton P.E., Model of normal prepubertal growth. Archives of Diseases of Childhood, 75:427-431, 1996

TAnner J.M., The morphological level of personality. Proceeding of Royal Soc. of Medicine, 40:301-303, 1947

TANner J.M., Rozwój w okresie pokwitania. PZWL, Warszawa 1963

Tanner J.M., A history of study of human growth. Cambridge University Press, Cambridge 1981

Togo M., Togo T., Time-series analysis of stature and body weight in five siblings. Annals of Human Biology, 9:425-440, 1982

Togo M., Togo T., Time-series analysis of stature, body weight and urinary excreted substances in five siblings. In "Human Growth and Development", pod red. J. Bormsa, R. Hauspiego, A. Sand, C. Susanna i M. Hebbelincka. Plenum Press, New York i Londyn 1984, str. 283-285

Togo M., Togo T., Initiation time of adolescent growth spurt estimated by a certain trough in time-series analysis of monthly anthropometric and urinanalysis data in five siblings, Human Biology, 60:223-235, 1988

Tuddenham R.D., Snyder M.M., Physical growth of California boys and girls from birth to eighteen years. University of California Publications in Child Development. 1:183-364, 1954

Uljaszek S.J., Johnston F.E., Preece M.A. (red), The Cambridge Encyclopedia of Human Growth and Development". Cambridge University Press, Cambridge 1998

WALES J.K.H., Gibson A.T., Short term growth: rhythms, chaos, or noise? Archives of Diseases of Childhood, 71:84-89, 1994

Wallau F., Körperbautypus und Menstruation. Zbl. Gynäk., 63:1830-1838, 1939

WelON Z., BIELICKI T., The timing of adolescent growth spurts of 8 body dimensions in boys and girls in the Wrocław Growth Study. Studies in Phys. Anthrop., 5:75-79, 1979

Wolański N., Krytyczny wiek w kształtowaniu postawy ciała. Chirurgia Narząów Ruchu i Ortopedia Polska, 23(2):129-134, 1958

Wolański N., Badania nad kształtowaniem się postawy ciała u dzieci i młodzieży miejskiej. Chirurgia Narządów Ruchu i Ortopedia Polska, 2:175-191, 1961a

Wolański N., Sposób oceny tempa, rytmu i harmonijności rozrostu dzieci. Pamiętnik XII Ogólnopolskiego Zjazdu Pediatrów: 23-31 + tabl. Warszawa 1961b

Wolański N., Kinetyka i dynamika rozwoju fizycznego dzieci i młodzieży (Kinetyka i dynamika rozrostu oraz różnicowania się proporcji ciała u dzieci i młodzieży warszawskiej [w wieku od 3 do 20 lat włacznie]). PZWL, Warszawa $1962 \mathrm{a}$ 
Wolański N., Rozwój fizyczny dziecka a rozpoczęcie nauki w szkole. Wychowanie Fizyczne i Higiena Szkolna, 2:23-28, 1962b

Wolański N., Z badań na tzw. skokiem pokwitaniowym u dziewcząt. Prace i Materiały Naukowe IMD, 3:181-196, 1964

WolaŃSKi N., Stan biologiczny i procesy integracyjne populacji miasta Szczecina w 25-leciu PRL. Przeglad Zachodnio-Pomorski, 14(4):5-39, 1970

Wolański N., Specyfika rozwoju fizycznego dzieci szczecinskich na tle czynników demograficznych i bytowych. W „Organizacja badan nad rozwojem $k$.f. i turystyki", 1:77-90, Szczecin 1972

WolaŃsKi N., Kierunki i przyczyny międzypokoleniowych przemian człowieka. Część I. Przemiany współczesnego człowieka, Kosmos. 6:665-673, 1979

Wolański N., Comparison of growth patterns of subcutaneous fat tissue in Mexican and Polish with US and Peruvian populations. Annals of Human Biology, 25(5):467-477, 1998a

Wolański N., Indices of body build and nutritional status. Journal of Human Ecology, 9(2):137-151, 1998b

Wolański N., Rozwój Biologiczny Człowieka. Podstawy Auksologii, Gerontologii i Promocji Zdrowia. Wydanie 7, Wydawnictwo Naukowe PWN, Warszawa 2005

Wolański N., Pyżuk M., Rozwój fizyczny w okresie dorastania i sposoby jego kontroli (ze szczególnym uwzględnieniem dojrzewania płciowego). Materiały do Nauczania Psychologii. Seria II. Psychologia Rozwojowa, Wychowawcza i Społeczna, 7:11-102, PWN, Warszawa 1970

Wolański N., Rojas A., Valentin G., Siniarska A., Każde dziecko i każda jego cecha ma swoiste tempo rozwoju, modyfikowane przez warunki życia w danym okresie (Raport 2, z dwuletnich comiesięcznych badań na Jukatanie w Meksyku). Studia Ecologiae et Bioethicae, 2:47-74, 2004

Wolański N., Valentin G., Rojas A., Siniarska A., Age, season at menarche, family factors and adult body traits in girls from Yucatan, Mexico (comparative study). Journal of Human Ecology, 9(1):1-17, 1998

Zieliśska A., Skok pokwitaniowy i budowa ciała dziewcząt z Meridy (Jukatan, Meksyk) jako sposób przystosowania do warunków życia. Studia Ecologiae et Bioethicae, 1:141-158, 2003 


\title{
Changes in the growth rate during ontogenesis and methods of its investigation
}

\begin{abstract}
The problem of acceleration of growing processes during childhood and adolescence has been considered for a long time. The observations on this subject date back to the $19^{\text {th }}$ century, however the attempts to summarize this phenomenon were dated to the $20^{\text {th }}$ century. At the beginning of the $20^{\text {th }}$ century Stratz, distinguishing the period of early and late childhood, had mentioned about three periods of deceleration and two periods of acceleration of growing processes. In 1930 also Boas identified the pubertal spurt. Ones of the first longitudinal studies had been organized in Krakow by TalkoHryncewicz and continued in 1919-32. The results had been elaborated by Jasicki in 1934-48 and he revealed that there are two periods of acceleration of growing processes. In Poland this acceleration in growth had been called "the maximal height velocity." The growth spurt at the end of childhood (around 7 years) has been pointed out by many authors in the 1930s, and in 1947 Tanner called it the mid-growth spurt. In 1961 Wolański pointed out that there are several growth spurts in childhood and called them pre (school) spurts. Consequently, in 1962 he had distinguished pubertal spurts for many somatic characteristics, and in 1964 - at least two pubertal spurts in height. Wolański had been analyzing the age at pubertal spurt followed by the age at menarche in rural and urban girls and concluded that these events are further apart if the pubertal spurt occurs later. The further analysis of these phenomena had been postponed because of the unfortunate statistical methods which presented data as mathematically smoothed growth curves and many details of individual growth patterns have been eliminated. Only two last decades the daily and monthly studies of growth processes have returned to favor, and the relationship between the rate and age at prepubertal and pubertal spurts has been studied again. In about 1980 the growth spurt at the turn of childhood and juvenile periods was again under study, but only during the last decade several growth spurts have been manifested. The number of prepubertal growth spurts has a very important impact on age and velocity of the pubertal spurt. If the number of prepubertal spurs is grater, the pubertal spurt occurs later and is less manifested. There are still many controversies according to the age of pubertal spurt and final body height. It may be similar to the relationship between menarche and final body height. It is observed that between populations there is a negative correlation between age at menarche and adult height, whereas between women within the population this correlation is positive (Wolański 1979).
\end{abstract}

